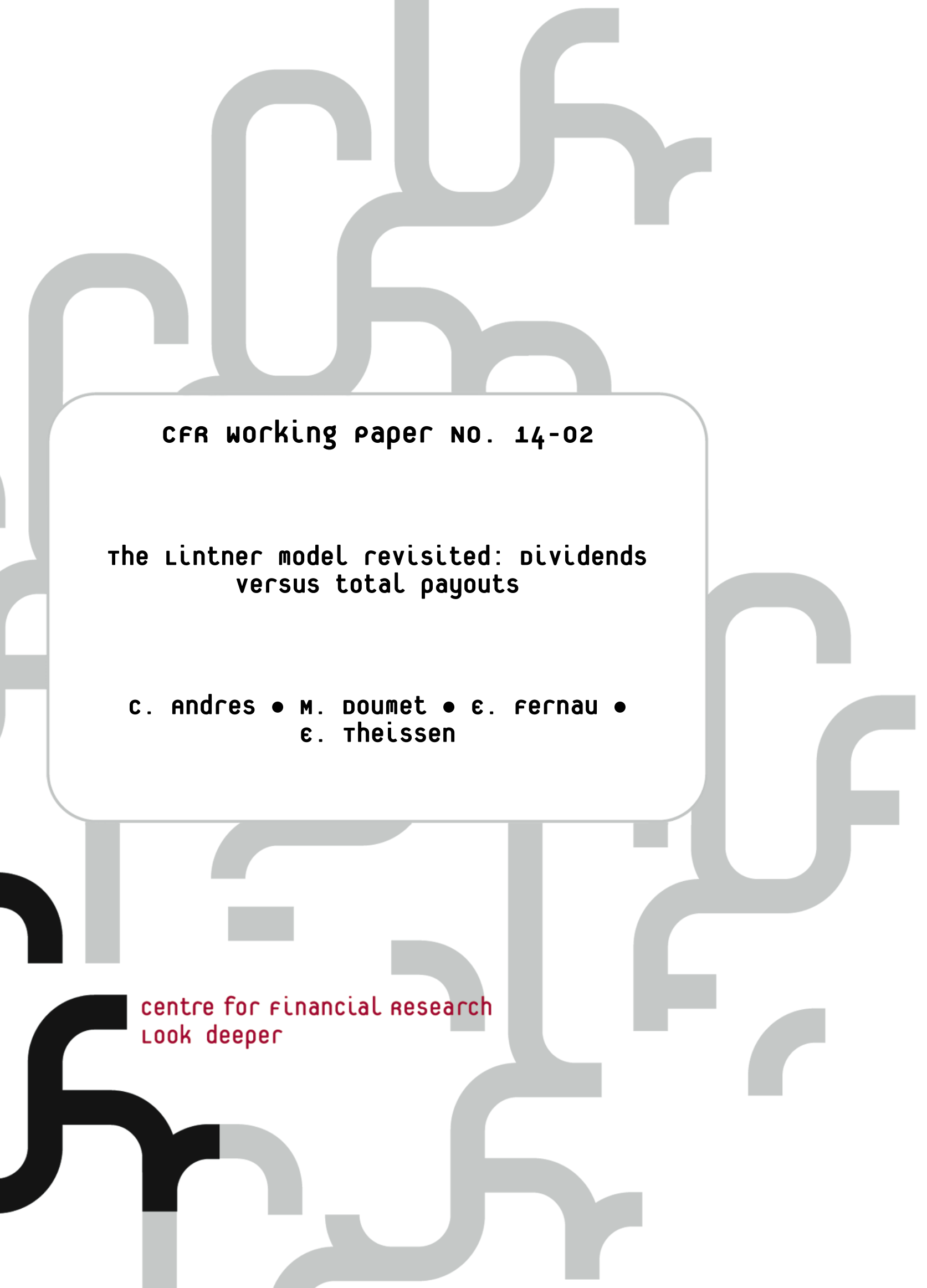




\title{
The Lintner model revisited: Dividends versus total payouts
}

\section{Christian Andres}

WHU - Otto Beisheim

School of Management

\author{
Markus Doumet \\ University of \\ Mannheim
}

\author{
Erik Fernau \\ University of \\ Mannheim
}

\author{
Erik Theissen \\ University of \\ Mannheim
}

October 2013

\begin{abstract}
We analyze how the introduction of repurchases in 1998, and a major tax reform in 2001, affected the payout policy of German firms. To this end, we estimate Lintner (1956) partial adjustment models for both dividends and total payouts. We also analyze the implications for payout of changes in both permanent and transitory earnings. Our results are inconsistent with the hypothesis that dividends and repurchases are perfect substitutes. They are also inconsistent with the prediction that tax considerations are a major driver of payout decisions. Our results instead support the flexibility hypothesis that predicts that dividends are used to disburse permanent, and repurchases transitory, earnings.
\end{abstract}

JEL classification: $\quad$ G32; G35

Keywords: $\quad$ Dividends, Repurchases, Lintner model 


\title{
The Lintner model revisited: Dividends versus total payouts
}

This version: October 2013

\begin{abstract}
We analyze how the introduction of repurchases in 1998, and a major tax reform in 2001, affected the payout policy of German firms. To this end, we estimate Lintner (1956) partial adjustment models for both dividends and total payouts. We also analyze the implications for payout of changes in both permanent and transitory earnings. Our results are inconsistent with the hypothesis that dividends and repurchases are perfect substitutes. They are also inconsistent with the prediction that tax considerations are a major driver of payout decisions. Our results instead support the flexibility hypothesis that predicts that dividends are used to disburse permanent, and repurchases transitory, earnings.
\end{abstract}

JEL classification: $\quad$ G32; G35

Keywords: $\quad$ Dividends; Repurchases; Lintner model 


\section{Introduction}

The question of how firms decide how much cash to disburse to shareholders has held the attention of financial economists for decades. Lintner's (1956) partial adjustment model, developed during a period in which dividends were the dominant form of payout, remains the workhorse of empirical investigations of corporate payout decisions. ${ }^{1}$ The volume of stock repurchases by listed U.S. firms having recently caught up with, and in some years surpassed, the volume of dividends (Grullon and Michaely, 2002), Skinner (2008, p. 608) concludes from his empirical evidence "that repurchases have become the dominant form of payout."

Yet Lintner's (1956) partial adjustment model of payout policy is in most empirical applications applied to dividend, rather than total, payouts. Few exceptions are found in the literature. Grullon and Michaely (2002) estimate a traditional dividend-based Lintner model and relate the resulting dividend errors (the difference between actual and predicted dividends) to repurchase volume. But Skinner's (2008) is the only paper of which we are aware that estimates a Lintner model based on total payouts using two restricted samples, one consisting of firms that repurchase and pay dividends in most years, the other consisting of firms that repurchase and never pay dividends. Thus far, no paper has estimated, for a comprehensive sample, a Lintner model of full payouts from which general conclusions might be drawn regarding the choice between dividends and repurchases.

\footnotetext{
1 For recent applications, see, among others, Andres et al. (2009), Chemmanur et al. (2010), and Skinner (2008). For a recent theoretical paper that builds on Lintner's model, see Lambrecht and Myers (2012). There are also, however, critics, among them, DeAngelo et al. (2008), who argue that the model has lost some of its descriptive ability, mostly because fewer firms have a well-defined target payout ratio.
} 
The correct specification depends on the economic drivers of the choice between dividends and stock repurchases. When each is a good substitute for the other (as argued by Miller and Modigliani, 1961, and would be the case in a world of perfect capital markets), the model should be better at explaining total payouts than dividends. Tax-based explanations predict that firms choose the payout method that yields the more favorable tax treatment. In this case, the correct model specification may depend on the tax regime. The financial flexibility hypothesis advanced by Jagannathan et al. (2000) states that dividends are used to pay out permanent, and stock repurchases transitory, earnings. In this case, estimation of a Lintner-type model entails decomposing earnings into permanent and transitory components.

In this paper, we put the cart before the horse. Estimating different versions of Lintner-type partial adjustment models enables us to infer the motives that underlie the choice between dividends and stock repurchases. Our sample, a large panel of German firms for which we collect data for the period 1988-2008, has two distinct advantages. The first, that stock repurchases were essentially prohibited until 1998, enables us to analyze how the introduction of an alternative to dividends affects corporate payout decisions. The second advantage, a major change in the tax system in 2001 that affected the relative attractiveness of dividends and stock repurchases, enables us to investigate the importance of tax considerations to corporate payout decisions generally, and the choice between dividends and stock repurchases, in particular.

Our results can be summarized as follows. The introduction of repurchases in 1998 has materially affected the payout policy of German firms, which is inconsistent with the hypothesis that dividends and repurchases are perfect substitutes. We find no evidence that German firms have altered their payout policy in response to the 2001 tax reform. Our results imply that dividends are more sticky than total payouts, which is consistent with the prediction of the 
flexibility hypothesis that dividends are paid predominantly out of permanent earnings. We further document that the responsiveness of dividends to changes in transitory earnings declined significantly in the wake of the introduction of repurchases, which evidence favors the flexibility hypothesis.

Our paper contributes to the literature in several ways. First, it is the first paper to use a partial adjustment model to analyze how the introduction of stock repurchases affects the magnitude and determinants of dividend payouts. Second, it tests whether a Lintner-type partial adjustment model is better suited to modeling dividend or total payouts. We do not, as Skinner (2008) does, restrict our sample to firms with a particular history of payout decisions. Third, it tests the hypothesis (advanced by Jagannathan et al., 2000) that dividends are used to disburse permanent, and stock repurchases temporary, earnings by decomposing earnings into permanent and temporary components and integrating them in a partial adjustment model. To the best of our knowledge, ours is the first paper that tests the flexibility hypothesis within a Lintner-type partial adjustment model. Our empirical analysis, which employs GMM-in-systems estimations, explicitly considers the role of special dividends (which, prior to the introduction of stock repurchases, might have been used to disburse temporary earnings).

The remainder of the paper is organized as follows. In section 2, we describe the German institutional setting. Our hypotheses are developed in section 3, the sample and descriptive statistics presented in section 4 . In section 5, we describe the econometric methodology and present our results. Section 6 concludes. 


\section{Institutional setting}

The German institutional framework provides an ideal environment in which to analyze our research questions. Stock repurchases were effectively prohibited during the first half of our sample period (1988-1997) and permitted with the enactment, in 1998, of a new law. There was also a major change in the tax system. Germany operated until 2001 under a full imputation system that favored dividend payouts over repurchases, which preference shifted for most investors, post reform, towards repurchases.

We describe below several aspects of the institutional environment of German firms as well as relevant changes over the sample period. Dividends are examined in section 2.1, stock repurchases in section 2.2, and the tax treatment of dividends and stock repurchases in section 2.3 .

\subsection{Dividends}

German firms pay annual (rather than quarterly) dividends. The payout decisions of German Stock Corporations (Aktiengesellschaften) are governed by $\S 58$ of the Stock Corporation Act (Aktiengesetz, AktG). ${ }^{2}$ Executive and supervisory boards can retain up to $50 \%$ of profits. The decision to retain or pay out the remaining amount is determined by a simple majority vote at a shareholders' meeting. In practice, shareholders' meetings almost invariably vote in favor of the

\footnotetext{
2 The following description relates to the standard procedure, from which articles of incorporation may permit deviations. Moreover, $\S 150 \mathrm{AktG}$ requires that a firm retain at least 5\% of its earnings, as long as the total amount of retained earnings amounts to less than $10 \%$ of dedicated capital (Grundkapital).
} 
executive board's proposal. The payment date is usually the business day following the day of the annual shareholders' meeting. ${ }^{3}$

Special designated dividends (Sonderdividenden) that firms may pay are of particular interest to the present study because they may be perfect substitutes for stock repurchases (DeAngelo et al., 2000). ${ }^{4}$ This is especially important in light of repurchases having been essentially prohibited until 1998.

\subsection{Stock repurchases}

Until 1998, when a new law allowed firms to buy back as much as $10 \%$ of their stock, repurchases were essentially prohibited in Germany. ${ }^{5,6}$ A firm wishing to buy back shares must

3 Some firms have issued both common and non-voting preferred shares. Claims of preferred shareholders, who are entitled to a cumulative minimum dividend ( $\$ 139 \mathrm{AktG}$ ), have priority over dividend payments to common shareholders. A minimum preferred dividend not paid in a given year is cumulated and must be paid out in later years. If the dividend is not paid for two consecutive years, owners of preferred shares are entitled to a voting right ( $\$ 140 \mathrm{AktG}$ ) until the cumulated minimum dividend has been paid. Non-voting shares are often entitled to an excess dividend, that is, a dividend larger by a specified amount than the dividend paid to common shareholders.

4 This view is supported by Brickley (1983), who finds, for a sample of U.S. firms, higher dividend payouts in the year following a dividend increase than in the year following a special designated dividend. These empirical results indicate that, relative to increases of regular dividends, special designated dividends are weaker signals of higher future payouts.

5 Firms could acquire their own shares only under restrictive conditions (e.g., to prevent damage). Although there is some disagreement in the literature as to the actual number of repurchases in Germany prior to 1998 (see Seifert, 2006, for a discussion), it is safe to conclude that stock repurchases were not used as a means of disbursing cash to shareholders prior to 1998 . 
follow a standardized procedure that begins with the managerial board securing permission (by means of a simple majority vote) at the shareholders' meeting. The maximum number of shares to be bought back (not more than $10 \%$ of shares outstanding) must be specified, together with the minimum and maximum price to be paid per share and duration of the permission (initially not longer than 18 months, increased to five years in 2008).

Permission authorizes, but does not oblige, a managerial board to buy back shares. ${ }^{7}$ The initiation of a repurchase program must be communicated to the public, as mandated by the German securities trading act (Wertpapierhandelsgesetz), which requires listed firms to immediately disclose information likely to materially affect security prices ("ad-hoc disclosure"). Empirical studies that analyze the impact of stock repurchase announcements on share prices typically use the date of ad-hoc disclosure as the event date (e.g., Gerke et al., 2002; Schremper, 2003; Seifert and Stehle, 2003; Hackethal and Zdantchouk, 2006; Bessler et al., 2012).

The requirement that firms treat all shareholders equally precludes negotiated repurchases from large shareholders. Open market repurchases (the dominant form), repurchase tender offers, and transferrable put rights are admissible, however.

As in the United States, announcement of a stock repurchase does not require the managerial board to actually repurchase shares. Amounts of repurchases are reported in firms' financial statements, enabling us to identify repurchase volumes in a fiscal year.

A new regulation adopted by the European Union in 2004 imposes additional restrictions on stock repurchases. Individual transactions made as part of a repurchase program must now be

\footnotetext{
${ }^{6}$ The $10 \%$ threshold applies to an individual repurchase program, not to the total amount of repurchases during the life of a firm.

${ }^{7}$ The decision to initiate a repurchase program is taken by the executive board and approved by the supervisory board.
} 
reported within seven trading days, and there are restrictions on the prices at which open market repurchases can be made (not higher than the price of the previous transaction) and on the maximum daily repurchase volume (not more than $25 \%$ of the average daily volume on the market on which the trade is made).

Finally, there are two ways in which a firm can handle repurchased shares. If reported on the asset side of the balance sheet, they can be used to cover outstanding convertible bonds or executive stock options. The maximum number of shares a firm can hold on its balance sheet is $10 \%$ of shares outstanding. Alternatively, repurchased shares can be used to reduce the number of shares outstanding, in which case a firm's book equity is reduced by the repurchase volume.

\subsection{Taxation of dividends and repurchases}

The tax treatment of dividends and repurchases underwent a major change in 2001. Until 2001, Germany operated under a full imputation system whereby dividends paid to domestic investors were essentially taxed at the investor's personal tax rate. ${ }^{8}$ Retained earnings were taxed at the corporate tax rate. Capital gains were tax exempt when the shares were held for more than six months (twelve months from 1999 onwards). Consequently, dividends were favored by investors with a personal tax rate below, repurchases by investors with a personal tax rate above, the corporate tax rate. The latter group was usually small, the corporate tax rate on retained earnings being quite close to the highest marginal tax rate on personal income. Corporate shareholders preferred dividends, which were tax free, whereas capital gains were taxed at the

\footnotetext{
8 Dividends were first taxed at the firm level. Domestic investors received the net dividend plus a tax credit equal to the tax paid by the firm. Gross dividends were taxed at investors' personal tax rate, with the resulting tax liability offset against the tax credit.
} 
corporate tax rate. Foreign investors, because they did not receive the tax credit, may have preferred repurchases.

Since 2001, dividends and retained earnings have been taxed at the corporate rate. At the personal investor level, half of the net dividend is taxed at the investor's personal tax rate, and capital gains, when the shares are held for more than one year, are not taxed. When this condition is met, individual investors should exhibit a clear preference for repurchases over dividends. For corporate investors, dividend payments were essentially tax-free and capital gains from the sale of shares held in other companies tax-exempt. ${ }^{9}$ Corporate investors were thus largely indifferent between dividends and repurchases.

In summary, prior to 2001 the preference for dividends versus repurchases depended on an investor's status (domestic versus foreign) and personal tax rate. Subsequent to the 2001 tax reform, we expect a clear preference for repurchases over dividends.

\section{Hypotheses}

Lintner's (1956) model is based on the assumption that firms have a target payout ratio such that changes in earnings translate into changes in payout. Adjustment is not immediate, however, firms only partially adjusting their payout towards new target levels. In its simplest form, the model yields the adjustment process

$$
\begin{aligned}
& \Delta D_{i, t}=\alpha_{i}+c_{i}\left(D_{i, t}^{*}-D_{i, t-1}\right)+u_{i, t} \\
& D_{i, t}^{*}=r_{i} P_{i, t}
\end{aligned}
$$

\footnotetext{
9 Since $2004,5 \%$ of received dividends must be declared as revenue and are therefore subject to the corporate tax rate.
} 
where $D_{i, t}$ denotes the dividend of firm $i$ in period $t, P_{i, t}$ profits, $D_{i, t}{ }^{*}$ the desired dividend payments, $r_{i}$ the target payout ratio for firm $i$, and $c_{i}$ the speed-of-adjustment coefficient.

Having been developed at a time when stock repurchases were rare, Lintner's model considered only dividend payouts. Despite the growing importance of repurchases, most researchers, Grullon and Michaely (2002) and Skinner (2008) being notable exceptions, have continued to use Lintner's framework and model only dividend payouts. Whether it is appropriate to model total payouts rather than dividend payouts is an open question that hinges on firms' motives for choosing dividends or repurchases.

In a world without differential tax treatment of dividends and repurchases or other frictions, the two payout methods would be perfect substitutes. ${ }^{10}$ In this case it would be appropriate to apply the Lintner model to total payouts rather than only to dividends. An implication of perfect substitutability is that a firm's total payout does not depend on the available menu of payout methods. Consequently, under perfect substitutability, the introduction of repurchases should not affect payout policy. This leads to our first hypothesis.

$H 1$ (perfect substitutes): The introduction of repurchases in 1998 does not affect the parameters of a Lintner model of total payout.

\footnotetext{
${ }^{10}$ The finding of Grullon and Michaely (2002) that U.S. firms increasingly replace dividends with repurchases is consistent with the view that dividends and repurchases are substitutes, though not necessarily perfect substitutes. Substitutability is consistent with principal-agent and signaling models of payout policy. The models of Easterbrook (1984) and Jensen (1986) imply that managers pay dividends in order to disburse free cash flow and thus reduce agency costs. A similar argument can be made in favor of repurchases. In signaling models of payout decisions (Bhattacharya, 1979; Miller and Rock, 1985), managers use dividends to signal information about future profitability. Repurchases could similarly be used as signals.
} 
When the tax system treats dividends and repurchases differently, firms have an obvious reason to prefer one payout method over the other. That the German tax reform in 2001 has made repurchases more attractive, as explained in section 2, gives us our second hypothesis.

H2 (taxes): The 2001 tax reform results in a reduction of the (target) dividend payout ratio and corresponding increase in the amount of repurchases.

So far we have assumed that (absent differential tax treatment) dividends and repurchases are perfect substitutes. This need not be the case, though. A firm's earnings may include both permanent and transitory components. Managers reluctant to increase dividends in response to high transitory earnings because the higher dividend level may not be sustainable typically try to avoid dividend cuts. ${ }^{11}$ Against this background, Jagannathan et al. (2000) have argued that firms use dividends to disburse permanent, and repurchases to pay out transitory, earnings. This is referred to as the flexibility hypothesis. Survey results reported in Brav et al. (2005) and the empirical evidence in Guay and Harford (2000) support this hypothesis.

H3 (flexibility / payout): Changes in dividend payouts are caused by changes in permanent, but unrelated to changes in transitory, earnings.

The flexibility hypothesis implies that repurchases track the more volatile transitory component of earnings. That we consequently expect repurchases to be adjusted quickly to changes in (transitory) earnings implies the following hypothesis.

\footnotetext{
${ }^{11}$ Michaely et al. (1995) show the negative market reaction after dividend cuts to be stronger than the positive market reaction after dividend increases.
} 
H4 (flexibility / speed of adjustment): The speed of adjustment coefficient will be larger in a Lintner model of total payout than in a Lintner model of dividends.

As noted in section 2, firms can use special designated dividends to disburse transitory cash flows. The flexibility hypothesis implies that firms used special dividends for that purpose prior to 1998 , when repurchases were essentially prohibited. When repurchases were permitted, the importance of special dividends should have declined, especially after the 2001 tax reform that put dividends at a disadvantage relative to repurchases.

H5 (special dividends): Special designated dividends lose importance after 1998.

Although DeAngelo et al. (2000) reject the hypothesis that repurchases displaced special dividends, we believe that the German setting, in which repurchases were prohibited prior to 1998, warrants reconsideration of this hypothesis.

Young firms tend to have volatile earnings and may therefore be reluctant to initiate dividend payments (Fama and French, 2001). They may, however, be willing to repurchase shares. ${ }^{12} \mathrm{We}$ therefore expect the fraction of firms that does not distribute cash to shareholders (using dividends or repurchases) to decrease after 1998.

H6 (fraction of non-payers): The fraction of firms that do not pay out cash to shareholders decreases after 1998.

\footnotetext{
${ }^{12}$ Typically, special dividends are declared in addition to regular dividends. Therefore, special designated dividends are not an alternative for these firms.
} 


\section{Sample and data description}

In this section we explain the construction of our sample and present summary statistics. The descriptive analysis provides an indication of the validity of some of our hypotheses.

\subsection{Sample selection}

Our sample includes all non-financial firms listed on the Frankfurt Stock Exchange that were among the largest 200 (as measured by total assets ${ }^{13}$ ) in Germany at any time during the 21 -year, 1988-2008 period. This results in an initial sample of 424 firms. Our sample covers, on average, $67.2 \%$ of the aggregate market capitalization of all listed firms in Germany.

Because firms subject to a control agreement do not decide payout independently, we drop firms-years in which such an agreement was in place. ${ }^{14}$ We further restrict our sample to firms with at least two consecutive firm-year observations. The resulting data set is an unbalanced panel with 4,363 firm-year observations.

Until 1998, domestic firms had to prepare their accounts according to German accounting standards. Between 1998 and 2004, they were allowed (but not required) to substitute international accounting standards (IAS/IFRS or US-GAAP). Application of IAS/IFRS has been mandatory since 2005. Because a change in accounting standards can significantly affect reported earnings, we use dummy variables to control for the accounting standards that were

\footnotetext{
${ }^{13}$ We measure total assets at year-end. If a firm's fiscal year is not the calendar year, we estimate the year-end value of total assets as a time-weighted average of the total assets in the previous and following fiscal years.

${ }^{14}$ A control agreement implies that a firm is effectively controlled by a parent company. For a detailed discussion, see Andres et al. (2009).
} 
applied. In a robustness check, we exclude the first firm-year after a change in accounting standards. ${ }^{15}$ The results, being similar, are omitted.

Balance sheet items, items from the income statement, and dividends were collected from Saling/Hoppenstedt Aktienführer, an annual publication that provides detailed information (e.g., ownership structure, board composition, and financial report information) on German listed firms. Values denominated in Deutsche Mark were converted to Euros at the official conversion rate. $^{16}$

Dividend information includes the nominal value and tax credit (under the imputation system in effect until 2001) as well as any special designated dividend. We also collect information on the number of shares outstanding. If a firm has several classes of shares (typically common shares and non-voting preferred shares), we calculate the total dividend payout. All values are adjusted for stock splits, stock dividends, and changes in dedicated capital (e.g., due to seasoned equity issues).

We further collect data on stock repurchases for the period 1998-2008. Because, as outlined in section 2, initiation of a repurchase must be publicly announced, the actual amount of repurchases must be published in the annual report. We use this information to infer amounts of repurchases in each fiscal year.

Because the annual dividend is typically paid by German firms in the second quarter of the fiscal year out of the previous year's earnings, we link each dividend payment to the fiscal year

\footnotetext{
${ }^{15}$ In the first year after a change in accounting standards, first-differenced earnings figures are calculated from two financial reports prepared according to different rules.

${ }^{16}$ The official conversion rate for 1998 was 1.95583 Deutsche Mark per Euro.
} 
preceding the year in which the dividend was paid. For example, we link the dividend paid in 2004 to earnings in 2003.

Matters are more complicated for repurchases. Repurchases that occurred early in 2004, for example, are likely to be related to 2003 earnings, whereas repurchases that occurred later in the year may well have been in response to interim earnings figures for 2004. In our baseline specification, we treat repurchases like dividends, that is, repurchases that occurred in 2004 are linked to 2003 earnings. As a robustness check, we implement an alternative specification; we link repurchases to the earnings of the year in which they occur (i.e., repurchases made in 2004 are linked to 2004 earnings). ${ }^{17}$

\subsection{Descriptive statistics}

Table 1 presents summary statistics for per-share earnings, total payouts, and regular dividends. Total payout is the sum of regular dividends (until 2001, including the tax credit), special dividends (also including the tax credit, when applicable), and repurchases (from 1998 onwards).

On average, firms pay out about two-thirds of their earnings, and regular dividends account for $51.8 \%$ of earnings. Total payouts are almost as volatile as earnings (coefficient of variation, 4.86, as compared to 5.43). Regular dividends are much less volatile, their coefficient of variation, 2.77, being about half the corresponding value for earnings. These results are consistent with the stylized fact that "regular dividends are what is smoothed, and not total payouts" (DeAngelo et al., 2008, p. 158). The finding that total payouts are much more volatile than dividends is inconsistent with the perfect substitutes hypothesis. Were dividends and

\footnotetext{
${ }^{17}$ Results are similar and not reported, but available upon request.
} 
repurchases perfect substitutes, there would be no reason to smooth dividends but not total payouts.

\section{[Insert Table 1 about here]}

Table 2 shows the evolution of dividend payout ratios, special dividend payout ratios, repurchase ratios, and total payout ratios over time. The payout ratios are also depicted in Figure 1. Dividend ratios appear to decrease over time. The average ratio for the pre-repurchase period $1988-1997$ is $56.4 \%$, the corresponding value for the repurchase period $1998-2008$ only $44.2 \%$. It is also noteworthy that (contrary to hypothesis $\mathrm{H} 2$ ) dividend payout ratios do not decrease after the 2001 tax reform.

Total payout ratios, on the other hand, change only slightly, from $57.7 \%$ to $53.7 \%$. Although these shifts are consistent with dividends being substituted by repurchases, the special dividend ratio increases rather than decreases, from $1.3 \%$ to $1.5 \%$. This is consistent with DeAngelo et al. (2000), but clearly inconsistent with our hypothesis H5.

Stock repurchases are much less important in Germany than in the United States. The highest repurchase ratio, $17.2 \%$, was observed in 2000 . That repurchase ratios are much lower than dividend ratios in any given year might be explained by the fact that repurchases were prohibited before 1998, and firms only slowly adopted this additional method of payout. But that the largest repurchase ratio in our sample was observed in 2000 casts doubt on this explanation. An alternative explanation for the low repurchase ratios is the restrictive regulation that requires advance approval by shareholders, and limits individual repurchase programs to no more than $10 \%$ of shares outstanding.

[Insert Table 2 about here]

[Insert Figure 1 about here] 
Table 3 shows the fraction of firms that increased, decreased, or held constant their dividend and total payout. The figures for dividends and total payouts being almost identical, we concentrate on the former. Dividends are unchanged in more than $35 \%$ of cases. We observe more increases (about 40\%) than decreases and omissions (together, 28.3\%). This pattern is consistent with managers being reluctant to cut dividends (and total payouts). Similar asymmetry between increases and decreases has been reported for the United States (e.g., Jagannathan et al., 2000; Skinner, 2008) and Germany (Andres et al., 2009).

[Insert Table 3 about here]

As argued above, we expect the fraction of firms that does not distribute earnings to shareholders to decrease subsequent to the authorization of stock repurchases in 1998 . We therefore divide our sample firms into two groups, those that pay dividends in a particular year, and those that do not. The latter group is further decomposed into two subgroups, firms that pay no dividend in a particular year but have paid a dividend in earlier years, and firms that never paid a dividend. The fraction of sample firms in each of these four groups is depicted in Figure 2. The fraction of dividend-paying firms decreased steadily until about 2003, then rebounded. It is noteworthy that the fraction of dividend-paying firms appeared to increase rather than decrease with the authorization of repurchases in 1998. The fraction of non-paying firms being the complement of the fraction of paying firms is, of itself, not interesting. What is interesting, though, is the decomposition into former payers and firms that never paid dividends to shareholders. The fraction of the latter group had been close to zero until 1997, began to increase in 1998, and reached a plateau in 2001, where it remained for several years, evidencing a slight decline after 2005. 
The increase in the fraction of firms that never paid out dividends coincides with the introduction of repurchases in 1998 and with the hot IPO market at the end of the 1990s. Newly listed firms thus either use repurchases to disburse cash to shareholders or do not disburse cash at all. We find the latter to be the dominant case. Firms that never paid dividends (287 firm-year observations in the 1998-2008 period) also tended not to repurchase shares. Our data set contains only 35 firm-year observations (12.2\%) in which a firm that never paid a dividend repurchased shares.

[Insert Figure 2 about here]

\section{Methodology and results}

The descriptive statistics presented in the previous section give some indication of the validity of our hypotheses. We pursue further conclusions by running a set of multivariate regressions derived from Lintner's (1956) model of dividend payouts. We explain below how the original model is adapted to test changes in the payout policy of our sample firms.

\subsection{Model specifications}

The starting point of our analysis is Lintner's (1956) model in its simplest form ${ }^{18}$

$$
\begin{aligned}
& \Delta \mathrm{D}_{\mathrm{i}, \mathrm{t}}=\mathrm{\alpha}_{\mathrm{i}}+\mathrm{c}_{\mathrm{i}}\left(\mathrm{D}_{\mathrm{i}, \mathrm{t}}^{*}-\mathrm{D}_{\mathrm{i}, \mathrm{t}-1}\right)+\mathrm{u}_{\mathrm{i}, \mathrm{t}} \\
& \mathrm{D}_{\mathrm{i}, \mathrm{t}}^{*}=\mathrm{r}_{\mathrm{i}} \mathrm{P}_{\mathrm{i}, \mathrm{t}}
\end{aligned}
$$

\footnotetext{
${ }^{18}$ Estimating a model in which we include lagged earnings, as suggested by Fama and Babiak (1968), yields similar results (unreported, but available upon request).
} 
where $\alpha_{i}$ is a constant, $c_{i}$ is the speed of adjustment coefficient, $P_{i, t}$ are after-tax earnings, $D_{i, t}$ are dividend payments, $\Delta \mathrm{D}_{\mathrm{i}, \mathrm{t}}$ is the change in dividend payments, $\mathrm{D}_{\mathrm{i}, \mathrm{t}}{ }^{*}$ are the desired dividend payments, and $r_{i}$ is the target payout ratio for firm i. Equation (1) models partial adjustment towards the desired level of dividends $\mathrm{D}_{\mathrm{i}, \mathrm{t}}{ }^{*}$, provided that $0 \leq \mathrm{c}_{\mathrm{i}} \leq 1$. The two polar cases correspond to complete adjustment $\left(\mathrm{c}_{\mathrm{i}}=1\right)$ and no adjustment $\left(\mathrm{c}_{\mathrm{i}}=0\right)$ towards the desired payout level.

Substitution of (2) into (1) yields

$$
\Delta \mathrm{D}_{\mathrm{i}, \mathrm{t}}=\alpha_{\mathrm{i}}+\mathrm{b}_{\mathrm{i}} \mathrm{P}_{\mathrm{i}, \mathrm{t}}+\mathrm{d}_{\mathrm{i}} \mathrm{D}_{\mathrm{i}, \mathrm{t}-1}+\mathrm{u}_{\mathrm{i}, \mathrm{t}}
$$

where $b_{i}=c_{i} r_{i}$ and $d_{i}=\left(1-c_{i}\right)$. It is common to assume the target payout ratio and speed of adjustment coefficient to be constant across firms (Andres et al., 2009; Fama, 1974; Skinner, 2008). Adding year-fixed effects $\left(\mathrm{YEAR}_{\mathrm{t}}\right)^{19}$ and firm-fixed effects $\left(\eta_{\mathrm{i}}\right)$ to capture firm-specific heterogeneity yields the baseline specification

$$
D_{i, t}=b P_{i, t}+d_{i, t-1}+Y_{E A R}+\eta_{i}+v_{i, t} .
$$

This specification considers only (regular) dividends. Denoting special dividends by $\mathrm{S}_{\mathrm{i}, \mathrm{t}}$ and repurchases by $\mathrm{R}_{\mathrm{i}, \mathrm{t}}$, we obtain a model based on total payouts

$$
\left(D_{i, t}+S_{i, t}+R_{i, t}\right)=b P_{i, t}+d\left(D_{i, t-1}+S_{i, t-1}+R_{i, t-1}\right)+Y_{E A R}+\eta_{i}+v_{i, t} .
$$

Under the perfect substitutes hypothesis, model (5) is a reasonable specification.

Hypothesis 1 states that the introduction of repurchases in 1998 does not affect the parameters of a Lintner model of total payouts. To test this hypothesis, we define, and interact with the independent variables of the total payout model (5), a dummy variable set to 0 before 1998 and to 1 from 1998 onwards. The coefficient estimates enable us to test whether the target

\footnotetext{
${ }^{19}$ We re-estimate all models without year-fixed effects and obtain qualitatively similar results.
} 
total payout ratio, speed of adjustment, or both changed after the introduction of repurchases in 1998.

Hypothesis 2 states that the 2001 tax reform should result in a reduction of dividend payout ratios. We test this hypothesis by augmenting our baseline (dividends-only) model (4) with a dummy variable set to 0 before the tax reform and to 1 thereafter. This dummy variable is also interacted with the independent variables. As above, the coefficient estimates enable us to test whether the target dividend payout ratio, speed of adjustment, or both changed after the tax reform.

The flexibility hypothesis (our hypothesis 3) states that dividends are paid out of permanent, and repurchases (and special dividends) out of transitory, earnings. Model (5) is an inappropriate specification because it does not differentiate between the two components of earnings.

We test the flexibility hypothesis by decomposing earnings into permanent and transitory components using the following simple procedure. We define permanent earnings PermP $_{\mathrm{i}, \mathrm{t}}$ to be the three-year moving average of earnings, ${ }^{20} \operatorname{Trans}_{\mathrm{i}, \mathrm{t}}$ the deviation between total and permanent earnings.

As a robustness check, we implement two alternative specifications; we use a five-year instead of three-year moving average, and estimate an AR(1)-model for each firm. The predicted values are interpreted as the permanent component, the residual as the transitory component, of

\footnotetext{
${ }^{20}$ Our choice of three-year moving averages is inspired by Guay and Harford (2000), who consider cash flow shocks to be the average of cash flows in years $\mathrm{t}=0$ and $\mathrm{t}=-1$, and measure the permanence of cash flow shocks as the difference between a three-year post-shock cash-flow period $(\mathrm{t}=1, \mathrm{t}=2$, and $\mathrm{t}=3)$ and three-year pre-shock cash-flow period $(\mathrm{t}=-4, \mathrm{t}=-3$ and $\mathrm{t}=-2)$.
} 
earnings. The results for these alternative specifications, being similar to those reported in Table 7, are omitted.

We estimate the following model.

$$
\mathrm{D}_{\mathrm{i}, \mathrm{t}}=\mathrm{bPermP}_{\mathrm{i}, \mathrm{t}}+\mathrm{kTrans}_{\mathrm{i}, \mathrm{t}}+\mathrm{dD}_{\mathrm{i}, \mathrm{t}-1}+\mathrm{YEAR}_{\mathrm{t}}+\eta_{\mathrm{i}}+\mathrm{v}_{\mathrm{i}, \mathrm{t}}
$$

If dividend changes reflect changes in permanent earnings, the coefficient $\mathrm{k}$ in equation (6) should, according to hypothesis 3, be zero. Moreover, because firms could not use repurchases to disburse temporary earnings prior to 1998 , there may be a structural break in 1998 . We address this issue by including a shift variable (and corresponding interaction terms) that measure differences between the period prior to 1998 and the period from 1998 onwards.

Under the flexibility hypothesis, positive transitory earnings are expected to result in repurchases or special dividends. To test this hypothesis, we define the variable $\operatorname{TransP}_{\mathrm{i}, \mathrm{t}}^{+}$, which equals the transitory earnings, as defined above, when positive, and zero when the transitory earnings are negative. We then estimate the following model based on repurchases and special dividends.

$$
\left(\mathrm{S}_{\mathrm{i}, \mathrm{t}}+\mathrm{R}_{\mathrm{i}, \mathrm{t}}\right)=\mathrm{bPermP}_{\mathrm{i}, \mathrm{t}}+\mathrm{kTrans}_{\mathrm{i}, \mathrm{t}}^{+}+\mathrm{d}\left(\mathrm{S}_{\mathrm{i}, \mathrm{t}-1}+\mathrm{R}_{\mathrm{i}, \mathrm{t}-1}\right)+\mathrm{YEAR}_{\mathrm{t}}+\eta_{\mathrm{i}}+\mathrm{v}_{\mathrm{i}, \mathrm{t}}
$$

We expect $k$ to be positive and $b$ to be zero.

\subsection{Estimation methods}

The models we estimate are dynamic panel data models with a relatively short time series ( $\mathrm{T}=21)$ and relatively large number of firms $(\mathrm{N}=424) \cdot{ }^{21}$ It is well known that in this case the OLS

\footnotetext{
${ }^{21} \mathrm{~T}=21$ is the maximum number of firm-years for an individual firm. Our dataset being an unbalanced panel, the average number of firm-years is much smaller, amounting to 11 years. Similarly, the average number of firm observations per year, 208, is smaller than the number of different firms in our sample.
} 
estimator yields upward-biased estimates of the coefficient on the lagged dependent variable. The within-group estimator (WG) (obtained by subtracting the firm-specific mean from all observations), on the other hand, yields downward-biased estimates (e.g., Bond, 2002; Nickel, 1981). Because consistent estimates can be obtained using GMM, we implement the GMM-insystems (GMM(SYS)) estimator (Blundell and Bond, 1998), which simultaneously estimates the equation in first differences with lagged levels as instruments and the equation in levels with lagged first differences as instruments.

We apply, in the implementation of the GMM(SYS) estimator, Roodman's (2009) rule of thumb, which states that the number of instruments should not exceed the number of crosssectional units (firms, in our case). We impose this restriction, then choose the instrument matrix with the highest p-value for the Hansen-test of over-identifying restrictions.

We report as well as the GMM estimator the OLS and WG estimators. The coefficient on lagged payout obtained using the GMM(SYS) estimator should lie between the estimators obtained using the OLS and WG estimators.

\subsection{Results}

For all model specifications, we report estimates based on OLS, together with the withingroup (WG) and GMM-in-systems (GMM(SYS)) estimators. We begin the analysis by estimating Lintner's (1956) original specification as a benchmark model. Columns (1) to (3) of Table 4 contain the coefficient estimates of this baseline specification (equation 4). The coefficients on the lagged dependent variable vary between 0.67 (WG) and 0.80 (OLS), with a GMM(SYS) coefficient estimate (0.68) that is much closer to the within-group estimator. These 
results confirm the prediction of an upward bias in OLS. The parameter estimates result in a speed of adjustment in the range of $[0.20,0.33]$, which is roughly in line with other studies that use German data (Andres et al., 2009; Behm and Zimmermann, 1993). The estimated target payout ratio (b/(1-d)) varies between $0.23(\mathrm{WG})$ and $0.48(\mathrm{GMM}(\mathrm{SYS}))$. Accordingly, estimates obtained via OLS and GMM(SYS) are quite close to the average dividend payout ratio over the full sample period (46.6\%, as documented in Table 2$)$.

Not surprisingly, the estimates of the target payout ratio are higher for the full payout model (columns (4) - (6)). These estimates are based on model specification (5), in which (regular) dividends, special dividends, and repurchases add up to total payout. Again, the results of the GMM(SYS) estimation (52.5\%) are quite close to the average total payout ratio (55.8\%), although the target payout ratio is only slightly higher than the estimates in columns (1) - (3). This points to the importance of dividends as German firms' main form of payout. When we compare speed of adjustment, the total payout model yields substantially higher estimates than the dividends-only model. This finding is consistent with hypothesis 4 , and indicates that (regular) dividends are, indeed, more sticky than total payouts.

\section{[Insert Table 4 about here]}

The models discussed thus far implicitly assume target payout ratios and speed of adjustment to be constant throughout the sample period. With the introduction of stock repurchases, the importance of (regular) dividends may have diminished, however. Our descriptive results in Table 2 do, indeed, show a decrease in average dividend payout ratio from $56.4 \%$ to $44.1 \%$. 
The results of a model specification that allows for a structural break in 1998 are reported in Table 5. Considering first the dividends-only model (columns (1) - (3) in Table 5), we find, as expected, a negative and highly significant (at the 5\% level or better) change in the target dividend payout ratio. Before 1998, the estimated target payout ratio varies between 0.49 and 0.70, and drops significantly when stock repurchases became legal (range [0.19, 0.47]. Estimates of speed of adjustment are also lower for the period after 1997. This implies that dividend payouts became even more sticky after repurchases were allowed. A possible explanation for this finding is that firms, to some extent, used dividends to disburse transitory earnings prior to 1998 , but ceased to do so when repurchases were permitted.

Columns (4) - (6) of Table 5 report the estimates for the total-payout model. ${ }^{22}$ The results show a substantial decrease in estimated target total payout ratio (from 0.79 to 0.49 ), and strong increase in speed of adjustment (from 0.51 to 0.88 , all figures relate to the GMM(SYS) estimation), after 1997. These results are inconsistent with the perfect substitutes hypothesis (H1), implying, rather, that dividends and repurchases are not perfect substitutes. Stock repurchases (and potentially also special dividends) accommodate more rapid adjustment to temporary changes in earnings, as reflected in the faster speed of adjustment during the second half of the sample period.

\footnotetext{
${ }^{22}$ There are 53 cases of firms announcing their intention to use share repurchases as a means of payment in future acquisitions ("acquisition currency"). Eliminating the corresponding 53 firm-year observations yields results similar to those presented in the text.
} 
As in Table 4, we find higher estimates of speed of adjustment with the total payout (columns (4) - (6)) than with the dividends-only (columns (1) - (3)) model. This adds to the evidence that supports hypothesis 4 .

\section{[Insert Table 5 about here]}

In sum, the findings in Table 5 indicate that German firms do not consider dividends and repurchases (perfect) substitutes.

As pointed out in section 2, a change in taxation in 2001 made repurchases relatively more desirable for the vast majority of investors. We therefore expect target dividend payout ratios to decrease after 2001 (hypothesis 2). To test this hypothesis, we extend the dividends-only model of Table 5 that allows for a structural break in 1998 to allow as well for a tax-induced structural break in 2002. The results are reported in Table 6. The coefficient estimates show substantial variation across sub-periods. We find payouts in later years to be much more rigid, as evidenced by a significantly lower speed of adjustment after 2001. The estimates of the target payout ratio are not within an economically meaningful range. The GMM-in-systems estimator implies a target payout ratio exceeding $100 \%$. Because the model specification with two structural breaks yields implausible results (possibly because the second sub-period is quite short), we abstain from modeling both structural breaks in further analyses, focusing instead on the main structural break in 1998.

To gain further insight into the impact of the tax reform on payout decisions, we re-estimate the model for the first (1988-97) and last (2002-08) sub-periods separately. These results are also reported in Table 6 (specification (4) and (5)). The target dividend payout ratio is 0.62 in 1988- 
97 and 0.72 in 2002-08. Both the joint estimation and separate estimations for the sub-periods thus yield results inconsistent with $\mathrm{H} 2$, which hypothesis predicts lower target dividend payout ratios after the tax reform. ${ }^{23}$ Our results thus imply that tax considerations do not seem to be a (first order) determinant of German firms' payout policy. This corroborates evidence reported in Andres et al. (2012). ${ }^{24}$

[Insert Table 6 about here]

The analysis thus far has shown speed of adjustment to generally be higher in a total payout than in a dividends-only model. This is consistent with the flexibility hypothesis of Jagannathan et al. (2000), which predicts changes in dividends to be related to changes in permanent, but unrelated to changes in temporary, earnings. To test of this hypothesis (our H3) directly, we decompose earnings into permanent and transitory components (see model (6) above). The model is estimated for dividends only, and allows for a structural break in 1998. Results are reported in Table 7. During the first half of the sample period, the coefficients of both permanent and transitory earnings are positive and highly statistically significant, and estimated target

\footnotetext{
${ }^{23}$ In a robustness check we estimate a model in which we include a tax discrimination variable to account for the specific tax preferences of the controlling shareholder. The discrimination variable is constructed following Andres et al. (2012). The results are similar to our baseline specification and are therefore not reported, but available upon request.

${ }^{24}$ Empirical results on the effect of the 2001 tax reform on German firms are inconclusive. Andres et al. (2012) find that the tax status the controlling shareholders has no impact on dividend decisions. In contrast, Kaserer et al. (2012) claim that German firms exhibit a lower propensity to pay dividends following the 2001 tax reform.
} 
payout ratios only slightly lower for transitory than for permanent earnings. This implies that, prior to the introduction of repurchases, firms used regular dividends to disburse transitory earnings.

With the introduction of stock repurchases, this picture changes. We observe a statistically significant structural break for both earnings components. Whereas the target payout ratio for permanent earnings decreases moderately (from 0.68 to 0.51 for the GMM(SYS) estimation), we observe a substantial and significant (at the $1 \%$ level) decrease for temporary earnings, from 0.66 to 0.26 (GMM(SYS)). Thus, in the period after 1997, the reaction of dividend payouts to changes in transitory earnings is much weaker than in the pre-1998 period. Speed of adjustment also decreases after 1997. Both results are consistent with the flexibility hypothesis (H3). Equipped by the introduction of stock repurchases in 1998 with a more flexible method of disbursing transitory earnings, firms no longer use regular dividends for this purpose.

[Insert Table 7 about here]

Whereas our measure of the transitory component of earnings can, by definition, be negative, the flexibility hypothesis implies that only positive deviations in earnings (i.e., positive transitory earnings) result in (temporary) payouts. We therefore run additional regressions in which only positive transitory earnings are considered to explain changes in special dividends and repurchases. Table 8 presents the results of this specification (model (7)). As expected, we find speed of adjustment to be quite high, lending further support to the notion that special dividends and repurchases are used as flexible means of payouts. In fact, the estimated speed of adjustment further increases with the introduction of stock repurchases. Surprisingly, the permanent earnings 
component has a significant and positive impact on special dividends before 1998. The coefficient on positive transitory earnings is also positive (and partly significant), but consistently lower in magnitude. This implies that special dividends were partly used to pay out permanent earnings. Special dividends and stock repurchases are not influenced by the permanent component of earnings during the second half of the sample period, however. Accordingly, the estimated target payout ratio of permanent earnings falls to almost zero (for GMM(SYS)). On the other hand, the target payout ratio for the (positive) transitory component of earnings increases strongly and significantly (at the $10 \%$ level), from 0.09 to 0.61 (GMM(SYS)). This can again be interpreted as evidence in favor of the flexibility hypothesis.

[Insert Table 8 about here]

\section{Conclusion}

The Lintner (1956) model, the workhorse of empirical research on corporate payout policy, is usually applied to dividend payouts, which is not necessarily appropriate against the background of the strong increase in repurchases. We argue that a comparison of Lintner models of dividend payout and total payout can yield insights into the drivers of the payout decision, enabling us to discriminate among alternative theories of corporate payout, namely, the perfect substitutes and flexibility hypotheses and tax-based explanations. These theories make specific predictions about target payout ratios and speed of adjustment coefficients in Lintner models of dividend payout and total payout.

A distinguishing feature of our dataset is that it spans the authorization, in 1998, of stock repurchases in Germany as well as a tax reform in 2001, enabling us to analyze how these events 
affected payout policy. We find that the introduction of repurchases in 1998 materially affected the payout policy of German firms. Our finding that the dividend and total target payout ratios decrease, and speed of adjustment decreases for dividend, but increases for total payout, is inconsistent with the perfect substitutes hypothesis, which predicts that the introduction of repurchases should not alter total payouts. Interestingly, special designated dividends do not lose importance subsequent to the introduction of repurchases.

We find no evidence that German firms have changed their payout policy in response to the 2001 tax reform. This finding, although it might seem surprising, is consistent with Andres et al.'s (2012) finding that the tax preferences of the largest shareholder have no impact on the dividend payout ratios of German firms.

Our results provide clear support for Jagannathan et al.'s (2000) financial flexibility hypothesis. Our finding that dividends are more rigid than total payouts is consistent with the prediction of the flexibility hypothesis that dividends are paid primarily out of permanent earnings. We further document that the responsiveness of dividends to changes in transitory earnings declined substantially after the introduction of repurchases. This finding also supports the flexibility hypothesis.

\section{Acknowledgments}

Financial support from Deutsche Forschungsgemeinschaft under grant TH724 2-1 is gratefully acknowledged. We thank participants in the 2013 HVB Doctoral Seminar in Passau for valuable comments. 


\section{References}

Andres, C., Betzer, A., Goergen, M., Renneboog, L., 2009. Dividend policy of German firms - a panel data analysis of partial adjustment models. Journal of Empirical Finance 16, 175-187.

Andres, C., Betzer, A., Goergen, M., 2012. Dividend policy, corporate control and the tax status of the controlling shareholder. Working paper, WHU - Otto Beisheim School of Management, University of Wuppertal, Cardiff Business School.

Behm, U., Zimmermann, H., 1993. The empirical relationship between dividends and earnings in Germany. Zeitschrift für Wirtschafts- und Sozialwissenschaften 113, 225-254.

Bessler, W., Drobetz, W., Seim, M., 2013. Share repurchases of initial public offerings: Motives, valuation effects, and the impact of market regulation. European Journal of Finance, forthcoming.

Bhattacharya, S., 1979. Imperfect information, dividend policy, and 'the bird in the hand' fallacy. Bell Journal of Economics 10, 259-270.

Blundell, R., Bond, S., 1998. Initial conditions and moment restrictions in dynamic panel data models. Journal of Econometrics 87, 115-143.

Bond, S., 2002. Dynamic panel data models: A guide to micro data methods and practice. Portuguese Economic Journal 1, 141-162.

Brav, A., Graham, J.R., Harvey, C.R., Michaely, R., 2005. Payout policy in the 21st century. Journal of Financial Economics 77, 483-527.

Brickley, J.A., 1983. Shareholder wealth, information signaling, and the specially designated dividend: An empirical study. Journal of Financial Economics 12, 187-209. 
Chemmanur, T.J., He, J., Hu, G., Liu, Y.H., 2010. Is dividend smoothing universal? New insights from a comparative study of dividend policies in Hong Kong and the U.S.. Journal of Corporate Finance 16, 413-430.

DeAngelo, H., DeAngelo, L., Skinner, D.J., 2000. Special dividends and the evolution of dividend signaling. Journal of Financial Economics 57, 309-354.

DeAngelo, H., DeAngelo, L., Skinner, D.J., 2008. Corporate payout policy. Foundations and Trends in Finance 3, 95-287.

Easterbrook, F.H., 1984. Two agency-cost explanations of dividends. American Economic Review 74, 650-659.

Fama, E.F., 1974. The empirical relationships between the dividend and investment decisions of firms. The American Economic Review 64, 304-318.

Fama, E.F. and Babiak, H., 1968. Dividend policy: An empirical analysis. Journal of the American Statistical Association 63, 1132-1161.

Fama, E.F. and French K.R., 2001. Disappearing dividends: Changing firm characteristics or lower propensity to pay? Journal of Financial Economics 60, 3-43.

Gerke, W., Fleischer, J., Langer, M., 2002. Kurseffekte durch Aktienrückkäufe - eine empirische Untersuchung für den deutschen Kapitalmarkt. In: Börsig, C., Coenenberg, A. G. (Eds.), Bewertung von Unternehmen: Strategie - Markt - Risiko, Kongress-Dokumentation 56. Deutscher Betriebswirtschafter-Tag, 275-304.

Grullon, G., Michaely R., 2002. Dividends, share repurchases and the substitution hypothesis. Journal of Finance 62, 1649-1684.

Guay, W., Harford, J., 2000. The cash-flow permanence and information content of dividend increases versus repurchases. Journal of Financial Economics 57, 385-415. 
Hackethal, A., Zdantchouk, A., 2006. Signaling power of open market share repurchases in Germany. Financial Markets and Portfolio Management 20, 123-151.

Jagannathan, M., Stephens, C.P., Weisbach, M.S., 2000. Financial flexibility and the choice between dividends and stock repurchases. Journal of Financial Economics, 355-384.

Jensen, M.C., 1986. Agency costs of free cash flow, corporate finance, and takeovers. American Economic Review 76, 323-329.

Kaserer, C., Trinchera, O., and Rapp, M.S., 2012. Payout policy, taxes, and corporate insiders: Evidence from the German tax reduction act 2001. Zeitschrift für Betriebswirtschaft 82, 85114.

Lambrecht, B.M. and Myers, S.C., 2012. A Lintner model of payouts and managerial rents. Journal of Finance 67, 1761-1810.

Lintner, J., 1956. Distribution of incomes of corporations among dividends, retained earnings, and taxes. American Economic Review 46, 97-113.

Michaely, R., Thaler, R.H. and Womack, K.L., 1995. Price reactions to dividend initiations and omissions: Overreaction or drift? Journal of Finance 50, 573-608.

Miller, M., Modigliani, F., 1961. Dividend policy, growth and the valuation of shares. Journal of Business 23, 411-433.

Miller, M., Rock, K., 1985. Dividend policy under asymmetric information. Journal of Finance $40,1031-1051$.

Nickel, S., 1981. Biases in dynamic models with fixed effects. Econometrica 49, 1417-1426.

Roodman, D., 2009. How to do xtabond2: An introduction to difference and system GMM in Stata. Stata Journal 9, 86-136. 
Schremper, R., 2003. Kapitalmarktrelevanz deutscher Aktienrückkaufprogramme. Zeitschrift für Betriebswirtschaftliche Forschung 55, 578-605.

Seifert, U., 2006. Aktienrückkäufe in Deutschland: Renditeeffekte und tatsächliche Volumina. Deutscher Universitäts-Verlag, Wiesbaden.

Seifert, U., Stehle R., 2003. Stock performance around share repurchase announcements in Germany. Working paper, Humboldt University.

Skinner, D.J., The evolving relation between earnings, dividends, and stock repurchases. Journal of Financial Economics 87, 582-609. 


\section{Table 1}

Summary statistics

This table provides summary statistics for dividends, total payout, and earnings in Euros per share. Total payout is defined as the sum of regular (gross) dividends, special dividends, and stock repurchases. The sample consists of 4,363 firm-year observations over the sample period from 1988 to 2008 . Because we do not have information on special dividends for 21 firm-year observations, the number of observations for total payout is reduced accordingly.

\begin{tabular}{cccc}
\hline & Earnings & Total payout & Dividends \\
\hline Mean & 15.35 & 10.13 & 7.95 \\
Standard deviation & 83.34 & 43.08 & 21.98 \\
Coefficient of variation & 5.43 & 4.86 & 2.77 \\
Median & 5.03 & 3.99 & 3.91 \\
Maximum & $2,278.00$ & $1,566.00$ & 399.42 \\
Minimum & -1.078 .43 & 0 & 0 \\
No. observations & 4,363 & 4,342 & 4,363 \\
\hline
\end{tabular}


Table 2

Aggregate payout ratios

This table provides annual information on payout ratios. The data consist of all firm-year observations with positive earnings (hence, the number of observations is lower than in Table 1). Yearly payout ratios are obtained by relating aggregate payouts (dividends and/or repurchases) to aggregate earnings $\sum_{i} E A R N . \sum_{i} D I V$ is the aggregate dividend payout per year expressed in millions of Euros. Accordingly, $\sum_{i} S P E C I A L$ is defined as the aggregate payout of special dividends, $\sum_{i} R E P$ as the aggregate repurchase volume, and $\sum_{i} T P$ as the sum of the three aforementioned items. We dropped two special dividends from the sample. Heidelberg Druckmaschinen AG paid a special dividend of $27.71 €$ in 1997. Altana AG paid a special dividend of $33.50 €$ in 2007 . This corresponds to a special payout volume of 2,833 Mio. $€$ and 4,732 Mio. $€$, corresponding to $77.54 \%$ and $61.98 \%$ of the pre-dividend market value of equity, respectively. We additionally report average payout ratios for the overall sample period (1988-2008), the period before the introduction of stock repurchases (1988-1997), and the period thereafter (1998-2008).

\begin{tabular}{|c|c|c|c|c|c|}
\hline Year & $\# O B S$ & $\begin{array}{c}\sum_{i} D I V / \\
\sum_{i} E A R N\end{array}$ & $\begin{array}{c}\sum_{i} S P E C I A L / \\
\sum_{i} E A R N\end{array}$ & $\begin{array}{c}\sum_{i} R E P / \\
\sum_{i} E A R N\end{array}$ & $\begin{array}{c}\sum_{i} T P / \\
\sum_{i} E A R N\end{array}$ \\
\hline 1988 & 147 & $70.34 \%$ & $1.73 \%$ & - & $72.07 \%$ \\
\hline 1989 & 158 & $65.42 \%$ & $0.36 \%$ & - & $65.78 \%$ \\
\hline 1990 & 164 & $51.16 \%$ & $1.15 \%$ & - & $52.31 \%$ \\
\hline 1991 & 170 & $68.97 \%$ & $1.11 \%$ & - & $70.08 \%$ \\
\hline 1992 & 136 & $35.08 \%$ & $0.12 \%$ & - & $35.20 \%$ \\
\hline 1993 & 149 & $73.89 \%$ & $0.87 \%$ & - & $74.76 \%$ \\
\hline 1994 & 151 & $70.89 \%$ & $3.66 \%$ & - & $74.55 \%$ \\
\hline 1995 & 170 & $61.22 \%$ & $1.57 \%$ & - & $62.79 \%$ \\
\hline 1996 & 164 & $55.33 \%$ & $0.51 \%$ & - & $55.84 \%$ \\
\hline 1997 & 155 & $55.48 \%$ & $3.16 \%$ & - & $58.64 \%$ \\
\hline 1998 & 181 & $62.44 \%$ & $0.50 \%$ & $0.02 \%$ & $62.96 \%$ \\
\hline 1999 & 193 & $58.91 \%$ & $1.04 \%$ & $2.51 \%$ & $62.46 \%$ \\
\hline 2000 & 227 & $39.95 \%$ & $0.63 \%$ & $17.15 \%$ & $57.73 \%$ \\
\hline 2001 & 224 & $39.09 \%$ & $4.24 \%$ & $9.05 \%$ & $52.39 \%$ \\
\hline 2002 & 179 & $39.90 \%$ & $1.69 \%$ & $1.64 \%$ & $43.24 \%$ \\
\hline 2003 & 169 & $45.04 \%$ & $1.98 \%$ & $2.43 \%$ & $49.44 \%$ \\
\hline 2004 & 157 & $47.47 \%$ & $0.26 \%$ & $6.81 \%$ & $54.53 \%$ \\
\hline 2005 & 182 & $46.21 \%$ & $0.55 \%$ & $4.62 \%$ & $51.38 \%$ \\
\hline 2006 & 184 & $49.27 \%$ & $0.41 \%$ & $5.06 \%$ & $54.74 \%$ \\
\hline 2007 & 192 & $43.06 \%$ & $1.15 \%$ & $6.71 \%$ & $50.92 \%$ \\
\hline 2008 & 179 & $36.90 \%$ & $2.33 \%$ & $16.56 \%$ & $55.79 \%$ \\
\hline $1988-97$ & 1,417 & $56.43 \%$ & $1.31 \%$ & - & $57.74 \%$ \\
\hline 1998-08 & 2,067 & $44.24 \%$ & $1.53 \%$ & $7.90 \%$ & $53.67 \%$ \\
\hline 1988-08 & 3,484 & $47.12 \%$ & $1.49 \%$ & $6.16 \%$ & $54.77 \%$ \\
\hline
\end{tabular}


Table 3

Type of payout change

This table shows the type and number of payout changes for each year of our sample. A firm can increase, decrease, or maintain its payout relative to the previous year. In the case of a decrease, a firm can either reduce or omit payouts. Total payout is defined as the sum of regular (gross) dividends, special dividends, and stock repurchases.

\begin{tabular}{|c|c|c|c|c|c|c|c|c|}
\hline \multirow[b]{2}{*}{ Year } & \multicolumn{4}{|c|}{ Dividends } & \multicolumn{4}{|c|}{ Total payout } \\
\hline & Increase & Maintain & Decrease & Omit & Increase & Maintain & Decrease & Omit \\
\hline 1988 & 45 & 77 & 24 & 4 & 38 & 65 & 22 & 4 \\
\hline 1989 & 65 & 72 & 19 & 3 & 67 & 70 & 19 & 3 \\
\hline 1990 & 76 & 65 & 19 & 3 & 76 & 65 & 19 & 3 \\
\hline 1991 & 72 & 58 & 40 & 10 & 76 & 58 & 36 & 10 \\
\hline 1992 & 53 & 53 & 48 & 19 & 53 & 52 & 49 & 19 \\
\hline 1993 & 40 & 71 & 39 & 11 & 42 & 70 & 38 & 11 \\
\hline 1994 & 67 & 32 & 83 & 15 & 67 & 31 & 84 & 15 \\
\hline 1995 & 87 & 63 & 35 & 5 & 83 & 62 & 40 & 5 \\
\hline 1996 & 80 & 58 & 47 & 19 & 74 & 58 & 53 & 19 \\
\hline 1997 & 72 & 61 & 52 & 16 & 73 & 60 & 52 & 14 \\
\hline 1998 & 97 & 62 & 28 & 6 & 94 & 63 & 30 & 6 \\
\hline 1999 & 82 & 82 & 39 & 6 & 81 & 79 & 43 & 6 \\
\hline 2000 & 86 & 54 & 66 & 8 & 92 & 50 & 64 & 7 \\
\hline 2001 & 130 & 48 & 61 & 8 & 124 & 47 & 68 & 7 \\
\hline 2002 & 67 & 58 & 108 & 25 & 66 & 56 & 111 & 25 \\
\hline 2003 & 61 & 113 & 55 & 23 & 62 & 108 & 59 & 23 \\
\hline 2004 & 115 & 70 & 36 & 17 & 109 & 66 & 46 & 19 \\
\hline 2005 & 86 & 73 & 58 & 8 & 90 & 67 & 60 & 9 \\
\hline 2006 & 107 & 97 & 16 & 6 & 102 & 92 & 26 & 8 \\
\hline 2007 & 100 & 98 & 23 & 11 & 106 & 82 & 33 & 10 \\
\hline 2008 & 108 & 91 & 19 & 11 & 115 & 73 & 30 & 12 \\
\hline $1988-97$ & $\begin{array}{c}657 \\
(39.3 \%)\end{array}$ & $\begin{array}{c}610 \\
(36.5 \%)\end{array}$ & $\begin{array}{c}406 \\
(24.3 \%)\end{array}$ & $\begin{array}{c}105 \\
(6.3 \%)\end{array}$ & $\begin{array}{c}649 \\
(39.3 \%)\end{array}$ & $\begin{array}{c}591 \\
(35.8 \%)\end{array}$ & $\begin{array}{c}412 \\
(24.9 \%)\end{array}$ & $\begin{array}{c}103 \\
(6.2 \%)\end{array}$ \\
\hline 1998-08 & $\begin{array}{c}1039 \\
(43.4 \%)\end{array}$ & $\begin{array}{c}846 \\
(35.3 \%)\end{array}$ & $\begin{array}{c}509 \\
(21.3 \%)\end{array}$ & $\begin{array}{c}129 \\
(5.4 \%)\end{array}$ & $\begin{array}{c}1041 \\
(43.5 \%)\end{array}$ & $\begin{array}{c}783 \\
(32.7 \%)\end{array}$ & $\begin{array}{c}570 \\
(23.8 \%)\end{array}$ & $\begin{array}{c}132 \\
(5.5 \%)\end{array}$ \\
\hline 1988-08 & $\begin{array}{c}1696 \\
(41.7 \%)\end{array}$ & $\begin{array}{c}1456 \\
(35.8 \%)\end{array}$ & $\begin{array}{c}915 \\
(22.5 \%)\end{array}$ & $\begin{array}{c}234 \\
(5.8 \%)\end{array}$ & $\begin{array}{c}1690 \\
(41.8 \%)\end{array}$ & $\begin{array}{c}1374 \\
(34.0 \%)\end{array}$ & $\begin{array}{c}982 \\
(24.3 \%)\end{array}$ & $\begin{array}{c}235 \\
(5.8 \%)\end{array}$ \\
\hline
\end{tabular}




\section{Table 4}

Classical Lintner model and total payout model

This table shows the results of OLS, within-groups (WG), and GMM-in-Systems (GMM(SYS)) regressions with dividends per share as the dependent variable (regression models 1-3). We also report results with total payout as the dependent variable (regression models 4-6). The number of observations is slightly lower for models 4-6 because in some cases we were unable to identify whether a special dividend was paid in addition to the regular dividend. The first column shows the independent variables. $\mathrm{D}_{\mathrm{i}, \mathrm{t}-1}$ and $\mathrm{S}_{\mathrm{i}, \mathrm{t}-1}$ are dividends and special dividends per share, respectively, paid out in the previous year. $\mathrm{R}_{\mathrm{i}, \mathrm{t}-1}$ corresponds to the repurchase volume per share in the previous year. $\mathrm{P}$ represents after-tax earnings per share. For the fixed-effects models, the coefficient for Constant is the average value of the fixed effects as obtained from Stata 12. Each cell shows the estimated coefficient and t-value (in parentheses). The superscripts $*, * *, * * *$ denote significance at the $10 \%, 5 \%$, and $1 \%$ levels, respectively. The statistics $\mathrm{m}_{1}$ and $\mathrm{m}_{2}$ are tests for the absence of first-order and second-order serial correlation in the residuals, asymptotically distributed as $\mathrm{N}(0,1)$ under the null of no serial correlation. The Hansen statistic is a test of the overidentifying restrictions, asymptotically distributed as $\chi^{2}(\mathrm{k})$ under the null of valid instruments, with $\mathrm{k}$ degrees of freedom reported in parentheses. All regressions include year dummies and a dummy indicating a change in accounting standards. Speed of adjustment is calculated as one minus the coefficient for $\mathrm{D}_{\mathrm{i}, \mathrm{t}-1}\left(\right.$ or $\left.\mathrm{D}_{\mathrm{i}, \mathrm{t}-1}+\mathrm{S}_{\mathrm{i}, \mathrm{t}-1}+\mathrm{R}_{\mathrm{i}, \mathrm{t}-1}\right)$. Target ratio equals the coefficient for $\mathrm{P}_{\mathrm{i}, \mathrm{t}}$ divided by Speed of adjustment.

\begin{tabular}{|c|c|c|c|c|c|c|}
\hline & \multicolumn{3}{|c|}{ Regular dividends } & \multicolumn{3}{|c|}{ Total payout } \\
\hline & OLS & WG & GMM(SYS) & OLS & WG & GMM(SYS) \\
\hline Constant & $\begin{array}{r}1.111 \\
(1.41)\end{array}$ & $\begin{array}{r}1.675 \\
(1.82)\end{array}$ & $\begin{array}{l}-0.168^{*} \\
(-0.17)\end{array}$ & $\begin{array}{l}2.937 * * * \\
(2.54)\end{array}$ & $\begin{array}{r}1.955 \\
(1.05)\end{array}$ & $\begin{array}{l}7.404 \\
(1.60)\end{array}$ \\
\hline $\mathbf{D}_{\mathrm{i}, \mathrm{t}-\mathbf{1}}$ & $\begin{array}{l}0.802^{* * *} \\
(6.89)\end{array}$ & $\begin{array}{l}0.666^{* * *} \\
(6.16)\end{array}$ & $\begin{array}{l}0.681^{* * *} \\
(5.95)\end{array}$ & - & - & - \\
\hline $\mathbf{D}_{\mathrm{i}, \mathrm{t}-\mathbf{1}}+\mathrm{S}_{\mathrm{i}, \mathrm{t}-\mathbf{1}}+\mathbf{R}_{\mathrm{i}, \mathrm{t}-1}$ & - & - & - & $\begin{array}{r}0.252 \\
(1.33)\end{array}$ & $\begin{array}{l}0.139 \\
(0.96)\end{array}$ & $\begin{array}{r}0.183 \\
(1.32)\end{array}$ \\
\hline $\mathbf{P}_{\mathrm{i}, \mathrm{t}}$ & $\begin{array}{l}0.083 * * \\
(2.14) \\
\end{array}$ & $\begin{array}{l}0.078 * * \\
(2.11) \\
\end{array}$ & $\begin{array}{l}0.154 * * * \\
(2.79)\end{array}$ & $\begin{array}{l}0.339 * * * \\
(2.68)\end{array}$ & $\begin{array}{l}0.320^{* *} \\
(2.40)\end{array}$ & $\begin{array}{l}0.429^{* * *} \\
(4.10)\end{array}$ \\
\hline $\mathbf{m}_{1}$ & - & - & -2.59 & - & - & -1.98 \\
\hline $\mathbf{m}_{2}$ & - & - & -1.08 & - & - & -1.30 \\
\hline $\begin{array}{c}\text { Hansen } \\
\text { (d.f) }\end{array}$ & - & - & $\begin{array}{r}334.22 \\
(316)\end{array}$ & - & - & $\begin{array}{r}339.90 \\
(313)\end{array}$ \\
\hline Observations & 3960 & 3960 & 3960 & 3909 & 3909 & 3909 \\
\hline Target ratio & 0.419 & 0.234 & 0.483 & 0.453 & 0.372 & 0.525 \\
\hline Speed of adj. & 0.198 & 0.334 & 0.319 & 0.748 & 0.861 & 0.817 \\
\hline
\end{tabular}


Table 5

Introduction of stock repurchases

This table shows the results of OLS, within-groups (WG), and GMM-in-Systems (GMM(SYS)) regressions with dividends per share as the dependent variable (regression models 1-3). We also report results with total payout as the dependent variable (regression models 4-6). The number of observations is slightly lower for models 4-6 because in some cases we were unable to identify whether a special dividend was paid in addition to the regular dividend. The first column shows the independent variables. $\mathrm{D}_{\mathrm{i}, \mathrm{t}-1}$ and $\mathrm{S}_{\mathrm{i}, \mathrm{t}-1}$ are dividends and special dividends per share, respectively, paid out in the previous year. $\mathrm{R}_{\mathrm{i}, \mathrm{t}-1}$ corresponds to the repurchase volume per share in the previous year. $\mathrm{P}$ represents after-tax earnings per share. For the fixed-effects models, the coefficient for Constant is the average value of the fixed effects as obtained from Stata 12. Each cell shows the estimated coefficient and t-value (in parentheses). The superscripts $*, * *, * * *$ denote significance at the $10 \%, 5 \%$, and $1 \%$ levels, respectively. We introduce a structural break to account for the introduction of stock repurchases in 1998. We report the coefficient for the period from 1998 onwards, which is the sum of the pre-break period (1988-1997) parameter and a shift term. We test whether the sum of the pre-break period parameter and shift term is statistically different from zero. We also report the standard t-test for the shift parameter and (in parentheses) t-value (note that the coefficient is the sum of the pre-break coefficient and shift parameter, whereas the t-statistic is for the shift parameter; there can thus be cases in which the parameter is positive and the $t$-statistic negative). The superscripts,,++++++ denote significance at the $10 \%, 5 \%$, and $1 \%$ levels, respectively. The statistics $\mathrm{m}_{1}$ and $\mathrm{m}_{2}$ are tests for the absence of first-order and secondorder serial correlation in the residuals, asymptotically distributed as $\mathrm{N}(0,1)$ under the null of no serial correlation. The Hansen statistic is a test of the over-identifying restrictions, asymptotically distributed as $\chi^{2}(\mathrm{k})$ under the null of valid instruments, with $\mathrm{k}$ degrees of freedom reported in parentheses. All regressions include year dummies and a dummy indicating a change in accounting standards. Speed of adjustment is calculated as one minus the coefficient for $\mathrm{D}_{\mathrm{i}, \mathrm{t}-1}$ (or $\left.\mathrm{D}_{\mathrm{i}, \mathrm{t}-1}+\mathrm{S}_{\mathrm{i}, \mathrm{t}-\mathrm{1}}+\mathrm{R}_{\mathrm{i}, \mathrm{t}-1}\right)$ in the respective period. Target ratio equals the coefficient for $\mathrm{P}_{\mathrm{i}, \mathrm{t}}$ divided by Speed of adjustment in the respective period.

\begin{tabular}{|c|c|c|c|c|c|c|}
\hline & \multicolumn{3}{|c|}{ Regular dividends } & \multicolumn{3}{|c|}{ Total payout } \\
\hline & OLS & WG & GMM(SYS) & OLS & WG & GMM(SYS) \\
\hline Constant & $\begin{array}{r}1.102 \\
(1.50)\end{array}$ & $\begin{array}{r}1.048 \\
(0.96)\end{array}$ & $\begin{array}{r}0.423 \\
(0.42)\end{array}$ & $\begin{array}{l}1.276 \\
(1.02)\end{array}$ & $\begin{array}{l}-0.075 \\
(-0.04)\end{array}$ & $\begin{array}{l}8.807 * * * \\
(2.13)\end{array}$ \\
\hline$D_{i, t-1}(88-97)$ & $\begin{array}{l}0.669 * * * \\
(16.77)\end{array}$ & $\begin{array}{l}0.613^{* * *} \\
(27.3)\end{array}$ & $\begin{array}{l}0.608^{* * *} \\
(47.44)\end{array}$ & - & - & - \\
\hline$D_{i, t-1}(98-08)$ & $\begin{array}{l}0.886^{* * *},+ \\
(2.26)\end{array}$ & $\begin{array}{l}0.735^{* * *} \\
(0.91)\end{array}$ & $\begin{array}{l}0.768^{* * *} \\
(1.14)\end{array}$ & - & - & - \\
\hline$D_{i, t-1}+S_{i, t-1}+R_{i, t-1}(88-97)$ & - & - & - & $\begin{array}{l}0.577^{* * *} \\
(15.10)\end{array}$ & $\begin{array}{l}0.476^{* * *} \\
(4.49)\end{array}$ & $\begin{array}{l}0.494^{* * *} \\
(9.11)\end{array}$ \\
\hline$D_{i, t-1}+S_{i, t-1}+R_{i, t-1}(98-08)$ & - & - & - & $\begin{array}{l}0.179^{++} \\
(-2.30)\end{array}$ & $\begin{array}{l}0.080^{++} \\
(-2.25)\end{array}$ & $\begin{array}{l}0.117^{+++} \\
(-3.07)\end{array}$ \\
\hline $\mathbf{P}_{\mathrm{i}, \mathrm{t}}(\mathbf{8 8 - 9 7 )}$ & $\begin{array}{l}0.196 * * * \\
(3.23)\end{array}$ & $\begin{array}{l}0.188 * * * \\
(2.93)\end{array}$ & $\begin{array}{l}0.274 * * * \\
(25.65)\end{array}$ & $\begin{array}{l}0.284 * * * \\
(3.24)\end{array}$ & $\begin{array}{l}0.274 * * * \\
(3.05)\end{array}$ & $\begin{array}{l}0.397 * * * \\
(43.90)\end{array}$ \\
\hline$P_{i, t}(\mathbf{9 8 - 0 8 )}$ & $\begin{array}{l}0.054 * *,+ \\
(-2.56)\end{array}$ & $\begin{array}{l}0.051 * *,+ \\
(-2.26)\end{array}$ & $\begin{array}{l}0.107^{* * *+++} \\
(-4.04)\end{array}$ & $\begin{array}{l}0.346^{* *} \\
(0.38)\end{array}$ & $\begin{array}{l}0.329 * * \\
(0.33)\end{array}$ & $\begin{array}{l}0.431 * * * \\
(0.28)\end{array}$ \\
\hline $\mathbf{m}_{1}$ & - & - & -2.74 & - & - & -1.98 \\
\hline $\mathbf{m}_{2}$ & - & - & -0.37 & - & - & -1.23 \\
\hline $\begin{array}{c}\text { Hansen } \\
\text { (d.f) }\end{array}$ & - & - & $\begin{array}{r}330.67 \\
(307)\end{array}$ & - & - & $\begin{array}{r}339.87 \\
(313)\end{array}$ \\
\hline Observations & 3960 & 3960 & 3960 & 3909 & 3909 & 3909 \\
\hline Target ratio (88-97) & 0.592 & 0.486 & 0.699 & 0.671 & 0.523 & 0.785 \\
\hline Target ratio (98-08) & 0.474 & 0.192 & 0.461 & 0.421 & 0.358 & 0.488 \\
\hline Speed of adj. (88-97) & 0.331 & 0.387 & 0.392 & 0.423 & 0.524 & 0.506 \\
\hline Speed of adj. (98-08) & 0.114 & 0.265 & 0.232 & 0.821 & 0.920 & 0.883 \\
\hline
\end{tabular}


Table 6

Tax reform

This table shows the results of OLS, within-groups (WG), and GMM-in-Systems (GMM(SYS)) regressions with dividends per share as the dependent variable. The number of observations is slightly lower for models 4-6 because in some cases we were unable to identify whether a special dividend was paid in addition to the regular dividend. The first column shows the independent variables. $\mathrm{D}_{\mathrm{i}, \mathrm{t}-1}$ represents dividends per share paid out in the previous year. $\mathrm{P}$ represents after-tax earnings per share. For the fixed-effects models, the coefficient for Constant is the average value of the fixed effects as obtained from Stata 12. Each cell shows the estimated coefficient and $\mathrm{t}$-value (in parentheses). The superscripts $*, * *, * * *$ denote significance at the $10 \%, 5 \%$, and $1 \%$ levels, respectively. We introduce two structural breaks to account for the introduction of stock repurchases in 1998 and the tax reform in 2001. We report coefficients for the periods 1998-2001 and 2002-2008, which are, in both cases, the sum of the prebreak period (1988-1997) parameter and a shift term. We test whether the sum of the 1988-1997 period parameter and the shift term is statistically different from zero. We also report the standard t-test for the shift parameter and (in parentheses) $t$-value (note that the coefficient is the sum of the pre-break coefficient and shift parameter, whereas the $\mathrm{t}$-statistic is for the shift parameter; there can thus be cases in which the parameter is positive and the $\mathrm{t}$-statistic negative). The superscripts,,++++++ denote significance at the $10 \%, 5 \%$, and $1 \%$ levels, respectively. The statistics $\mathrm{m}_{1}$ and $\mathrm{m}_{2}$ are tests for the absence of first-order and second-order serial correlation in the residuals, asymptotically distributed as $\mathrm{N}(0,1)$ under the null of no serial correlation. The Hansen statistic is a test of the overidentifying restrictions, asymptotically distributed as $\chi^{2}(\mathrm{k})$ under the null of valid instruments, with $\mathrm{k}$ degrees of freedom reported in parentheses. All regressions include year dummies and a dummy indicating a change in accounting standards. Speed of adjustment is calculated as one minus the coefficient for $\mathrm{D}_{\mathrm{i}, \mathrm{t}-\mathrm{i}}$ in the respective period. Target ratio equals the coefficient for $\mathrm{P}_{\mathrm{i}, \mathrm{t}}$ divided by Speed of adjustment in the respective period.

\begin{tabular}{|c|c|c|c|c|c|}
\hline & \multicolumn{5}{|c|}{ Regular dividends } \\
\hline & OLS & WG & GMM(SYS) & GMM(SYS) & GMM(SYS) \\
\hline \multirow[t]{2}{*}{ Constant } & 1.092 & 1.129 & -0.550 & 0.221 & $-2.830 * * *$ \\
\hline & $(1.49)$ & $(1.03)$ & $(-0.63)$ & $(0.55)$ & $(-2.60)$ \\
\hline \multirow{2}{*}{$D_{i, t-1}(88-97)$} & $0.671 * * *$ & $0.580 * * *$ & $0.582 * * *$ & $0.538 * * *$ & - \\
\hline & $(16.52)$ & $(28.81)$ & $(43.20)$ & $(30.20)$ & \\
\hline$D_{i, t-1}(98-01)$ & $\begin{array}{l}0.484 * * * \\
(-1.35)\end{array}$ & $\begin{array}{l}0.299 * *+ \\
(-1.90)\end{array}$ & $\begin{array}{l}0.322^{* * * *+} \\
(-1.80)\end{array}$ & - & - \\
\hline \multirow[t]{2}{*}{$D_{i, t-1}(02-08)$} & $1.008 * * *,++$ & $0.859 * * *$ & $0.941 * *$ & - & $0.880 * * *$ \\
\hline & $(3.73)$ & $(2.88)$ & $(3.43)$ & & $(7.78)$ \\
\hline \multirow{2}{*}{$P_{i, t}(88-97)$} & $0.196 * * *$ & $0.180 * * *$ & $0.280 * * *$ & $0.288 * * *$ & - \\
\hline & $(3.23)$ & $(2.85)$ & $(31.47)$ & $(44.30)$ & \\
\hline \multirow{2}{*}{$P_{i, t}(98-01)$} & $0.041^{++}$ & $0.033^{+++}$ & $0.250 * * *$ & - & - \\
\hline & $(-2.49)$ & $(-2.34)$ & $(-0.37)$ & & \\
\hline \multirow{2}{*}{$P_{\mathrm{i}, \mathrm{t}}(\mathbf{0 2 - 0 8 )}$} & $0.048 * *$ & $0.044 * *$ & $0.078 * *$ & - & $0.086 * *$ \\
\hline & $(-2.35)$ & $(-2.01)$ & $(-6.00)$ & & $(2.30)$ \\
\hline $\mathbf{m}_{1}$ & - & - & -2.77 & -1.67 & -1.47 \\
\hline $\mathbf{m}_{2}$ & - & - & -1.02 & -1.04 & -0.93 \\
\hline Hansen & - & - & 308.57 & 105.87 & 118.73 \\
\hline (d.f) & & & (232) & $(90)$ & (77) \\
\hline Observations & 3960 & 3960 & 3960 & 1648 & 1494 \\
\hline Target ratio (88-97) & 0.596 & 0.429 & 0.607 & 0.623 & - \\
\hline Target ratio (98-01) & 0.079 & 0.047 & 0.381 & - & - \\
\hline Target ratio (02-08) & -6.000 & 0.312 & 1.322 & - & 0.717 \\
\hline Speed of adj. (88-97) & 0.329 & 0.420 & 0.418 & 0.462 & - \\
\hline Speed of adj. (98-01) & 0.516 & 0.701 & 0.678 & - & - \\
\hline Speed of adj. (02-08) & -0.008 & 0.141 & 0.059 & - & 0.120 \\
\hline
\end{tabular}


Table 7

Financial flexibility: Dividends

This table shows the results of OLS, within-groups (WG), and GMM-in-Systems (GMM(SYS)) regressions with dividends per share as the dependent variable. The first column shows the independent variables. $\mathrm{D}_{\mathrm{i}, \mathrm{t}-1}$ are dividends per share paid out in the previous year. PermP represents the three-year moving average of after-tax earnings per share based on the years $t, t-1$, and $t-2$. Trans $P$ is equal to the difference between after-tax earnings per share and PermP. For the fixed-effects models, the coefficient for Constant is the average value of the fixed effects as obtained from Stata 12. Each cell shows the estimated coefficient and t-value (in parentheses). The superscripts $*, * *, * * *$ denote significance at the $10 \%, 5 \%$, and $1 \%$ levels, respectively. We introduce a structural break to account for the introduction of stock repurchases in 1998. We report the coefficient for the period from 1998 onwards, which is the sum of the pre-break period parameter and a shift term. We test whether the sum of the pre-break period (19881997) parameter and shift term is statistically different from zero. We also report the standard t-test for the shift parameter and (in parentheses) t-value (note that the coefficient is the sum of the pre-break coefficient and shift parameter, whereas the t-statistic is for the shift parameter; there can thus be cases in which the parameter is positive and the t-statistic negative). The superscripts,,++++++ denote significance at the $10 \%, 5 \%$, and $1 \%$ levels, respectively. The statistics $\mathrm{m}_{1}$ and $\mathrm{m}_{2}$ are tests for the absence of first-order and second-order serial correlation in the residuals, asymptotically distributed as $\mathrm{N}(0,1)$ under the null of no serial correlation. The Hansen statistic is a test of the over-identifying restrictions, asymptotically distributed as $\chi^{2}(\mathrm{k})$ under the null of valid instruments, with $\mathrm{k}$ degrees of freedom reported in parentheses. All regressions include year dummies and a dummy indicating a change in accounting standards. Speed of adjustment is calculated as one minus the coefficient for $\mathrm{D}_{\mathrm{i}, \mathrm{t}-1}$ in the respective period. Target ratio perm (trans) equals the coefficient for Perm $\mathrm{P}_{\mathrm{i}, \mathrm{t}}\left(\operatorname{Trans} \mathrm{P}_{\mathrm{i}, \mathrm{t}}\right)$ divided by Speed of adjustment in the respective periods.

\begin{tabular}{|c|c|c|c|}
\hline & \multicolumn{3}{|c|}{ Regular dividends } \\
\hline & OLS & WG & GMM(SYS) \\
\hline Constant & $\begin{array}{r}0.592 \\
(1.17)\end{array}$ & $\begin{array}{l}0.668 \\
(0.83)\end{array}$ & $\begin{array}{l}-0.041 \\
(-0.04)\end{array}$ \\
\hline$D_{i, t-1}(88-97)$ & $\begin{array}{l}0.643^{* * *} \\
(11.58)\end{array}$ & $\begin{array}{l}0.567^{* * *} \\
(21.94)\end{array}$ & $\begin{array}{l}0.589 * * * \\
(20.60)\end{array}$ \\
\hline$D_{i, t-1}(98-08)$ & $\begin{array}{l}0.793 * * * \\
(1.30)\end{array}$ & $\begin{array}{l}0.603^{* * * *} \\
(0.25)\end{array}$ & $\begin{array}{l}0.673 * * * \\
(0.59)\end{array}$ \\
\hline $\operatorname{PermP}_{\mathrm{i}, \mathrm{t}}(\mathbf{8 8 - 9 7 )}$ & $\begin{array}{l}0.206^{* * *} \\
(2.98)\end{array}$ & $\begin{array}{l}0.218^{* * * *} \\
(2.96)\end{array}$ & $\begin{array}{l}0.279 * * * \\
(10.30)\end{array}$ \\
\hline $\operatorname{PermP}_{\mathrm{i}, \mathrm{t}}(\mathbf{9 8 - 0 8 )}$ & $\begin{array}{l}0.112^{* *},+ \\
(-1.84)\end{array}$ & $\begin{array}{l}0.131^{*}+ \\
(1.55)\end{array}$ & $\begin{array}{l}0.168^{* * *+++}, \\
(-3.13)\end{array}$ \\
\hline $\operatorname{Trans}_{\mathrm{i}, \mathrm{t}}(\mathbf{8 8 - 9 7 )}$ & $\begin{array}{l}0.194 * * * \\
(3.30)\end{array}$ & $\begin{array}{l}0.182^{* * *} \\
(2.86)\end{array}$ & $\begin{array}{l}0.273^{* * *} \\
(75.16)\end{array}$ \\
\hline $\operatorname{Trans}_{\mathrm{i}, \mathrm{t}}(\mathbf{9 8 - 0 8 )}$ & $\begin{array}{l}0.013^{+++} \\
(-2.67)\end{array}$ & $\begin{array}{l}0.006^{+++} \\
(-2.40)\end{array}$ & $\begin{array}{l}0.085^{* *},++ \\
(-5.07)\end{array}$ \\
\hline $\mathbf{m}_{1}$ & - & - & -2.99 \\
\hline $\mathbf{m}_{2}$ & - & - & -0.41 \\
\hline $\begin{array}{c}\text { Hansen } \\
\text { (d.f) }\end{array}$ & - & - & $\begin{array}{r}337.28 \\
(315)\end{array}$ \\
\hline Observations & 3581 & 3581 & 3581 \\
\hline Target ratio perm (88-97) & 0.577 & 0.503 & 0.679 \\
\hline Target ratio perm (98-08) & 0.541 & 0.330 & 0.514 \\
\hline Target ratio trans (88-97) & 0.543 & 0.420 & 0.664 \\
\hline Target ratio trans (98-08) & 0.063 & 0.015 & 0.260 \\
\hline Speed of adj. (88-97) & 0.357 & 0.433 & 0.411 \\
\hline Speed of adj. (98-08) & 0.207 & 0.397 & 0.327 \\
\hline
\end{tabular}




\section{Table 8}

Financial flexibility: Special dividends and repurchases

This table shows the results of OLS, within-groups (WG), and GMM-in-Systems (GMM(SYS)) regressions with the sum of special dividends and stock repurchases per share as the dependent variable. The first column shows the independent variables. $\mathrm{S}_{\mathrm{i}, \mathrm{t}-1}$ are special dividends per share paid out in the previous year. $\mathrm{R}_{\mathrm{i}, \mathrm{t}-1}$ corresponds to the repurchase volume per share in the previous year. PermP represents the three-year moving average of after-tax earnings per share based on the years $\mathrm{t}, \mathrm{t}-1$, and $\mathrm{t}-2$. Positive Trans $\mathrm{P}$ is equal to the maximum of the difference between after-tax earnings per share and PermP and zero. For the fixed-effects models, the coefficient for Constant is the average value of the fixed effects as obtained from Stata 12. Each cell shows the estimated coefficient and tvalue (in parentheses). The superscripts $*, * *, * * *$ denote significance at the $10 \%, 5 \%$, and $1 \%$ levels, respectively. We introduce a structural break to account for the introduction of stock repurchases in 1998. We report the coefficient for the period from 1998 onwards, which is the sum of the pre-break period (1988-1997) parameter and a shift term. We test whether the sum of the pre-break period parameter and shift term is statistically different from zero. We also report the standard t-test for the shift parameter and (in parentheses) t-value (note that the coefficient is the sum of the pre-break coefficient and shift parameter, whereas the t-statistic is for the shift parameter; there can thus be cases in which the parameter is positive and the t-statistic negative). The superscripts,,++++++ denote significance at the $10 \%, 5 \%$, and $1 \%$ levels, respectively. The statistics $m_{1}$ and $m_{2}$ are tests for the absence of firstorder and second-order serial correlation in the residuals, asymptotically distributed as $\mathrm{N}(0,1)$ under the null of no serial correlation. The Hansen statistic is a test of the over-identifying restrictions, asymptotically distributed as $\chi^{2}(\mathrm{k})$ under the null of valid instruments, with $\mathrm{k}$ degrees of freedom reported in parentheses. All regressions include year dummies and a dummy indicating a change in accounting standards. Speed of adjustment is calculated as one minus the coefficient for $\mathrm{D}_{\mathrm{i}, \mathrm{t}-1}$ in the respective period. Target ratio perm (trans) equals the coefficient for PermP $\mathrm{P}_{\mathrm{i}, \mathrm{t}}$ (Trans $\mathrm{P}_{\mathrm{i}, \mathrm{t}}$ ) in the respective period divided by Speed of adjustment in the respective period.

\begin{tabular}{|c|c|c|c|}
\hline & \multicolumn{3}{|c|}{ Special dividends + repurchases } \\
\hline & OLS & WG & GMM(SYS) \\
\hline Constant & $\begin{array}{l}-1.350^{* *} \\
(-2.43)\end{array}$ & $\begin{array}{l}-2.605 * * \\
(-2.36)\end{array}$ & $\begin{array}{l}2.740 \\
(0.52)\end{array}$ \\
\hline$S_{i, t-1}+R_{i, t-1}(\mathbf{8 8}-97)$ & $\begin{array}{l}0.167 * * \\
(2.43)\end{array}$ & $\begin{array}{r}0.074 \\
(0.66)\end{array}$ & $\begin{array}{l}0.157 \\
(2.11)\end{array}$ \\
\hline$S_{i, t-1}+R_{i, t-1}(\mathbf{9 8 - 0 8})$ & $\begin{array}{l}-0.034^{+++} \\
(-3.12)\end{array}$ & $\begin{array}{l}-0.083 \\
(-1.47)\end{array}$ & $\begin{array}{l}-0.038^{+++} \\
(-2.61)\end{array}$ \\
\hline $\operatorname{Perm}_{\mathrm{i}, \mathrm{t}}(\mathbf{8 8 - 9 7 )}$ & $\begin{array}{l}0.140^{* * * *} \\
(4.40)\end{array}$ & $\begin{array}{l}0.195^{* * * *} \\
(3.87)\end{array}$ & $\begin{array}{l}0.142 * * * \\
(5.36)\end{array}$ \\
\hline $\operatorname{PermP}_{\mathrm{i}, \mathrm{t}}(\mathbf{9 8 - 0 8 )}$ & $\begin{array}{r}0.124 \\
(-0.18)\end{array}$ & $\begin{array}{r}0.143 \\
(-0.58)\end{array}$ & $\begin{array}{r}0.009 \\
(-0.12)\end{array}$ \\
\hline Positive Trans $P_{i, t}(88-97)$ & $\begin{array}{l}0.060^{* *} \\
(2.21)\end{array}$ & $\begin{array}{l}0.060 \\
(1.33)\end{array}$ & $\begin{array}{l}0.073^{* * * *} \\
(7.54)\end{array}$ \\
\hline Positive TransP $P_{i, t}(98-08)$ & $\begin{array}{l}0.407 \\
(1.18)\end{array}$ & $\begin{array}{r}0.444 \\
(1.21)\end{array}$ & $\begin{array}{l}0.634^{*}, \\
(1.71)\end{array}$ \\
\hline $\mathbf{m}_{1}$ & - & - & -1.37 \\
\hline $\mathbf{m}_{2}$ & - & - & -1.63 \\
\hline $\begin{array}{c}\text { Hansen } \\
\text { (d.f) }\end{array}$ & - & - & $\begin{array}{r}296.22 \\
(177)\end{array}$ \\
\hline Observations & 3553 & 3553 & 3553 \\
\hline Target ratio perm (88-97) & 0.168 & 0.211 & 0.168 \\
\hline Target ratio perm (98-08) & 0.120 & 0.132 & 0.009 \\
\hline Target ratio trans (88-97) & 0.072 & 0.065 & 0.087 \\
\hline Target ratio trans (98-08) & 0.394 & 0.410 & 0.611 \\
\hline Speed of adj. (88-97) & 0.833 & 0.926 & 0.843 \\
\hline Speed of adj. (98-08) & 1.034 & 1.083 & 1.038 \\
\hline
\end{tabular}




\section{Figure 1}

Composition of total payout

This figure depicts the composition of total payout over the sample period from 1988-2008. All ratios are based on gross payouts relative to earnings.

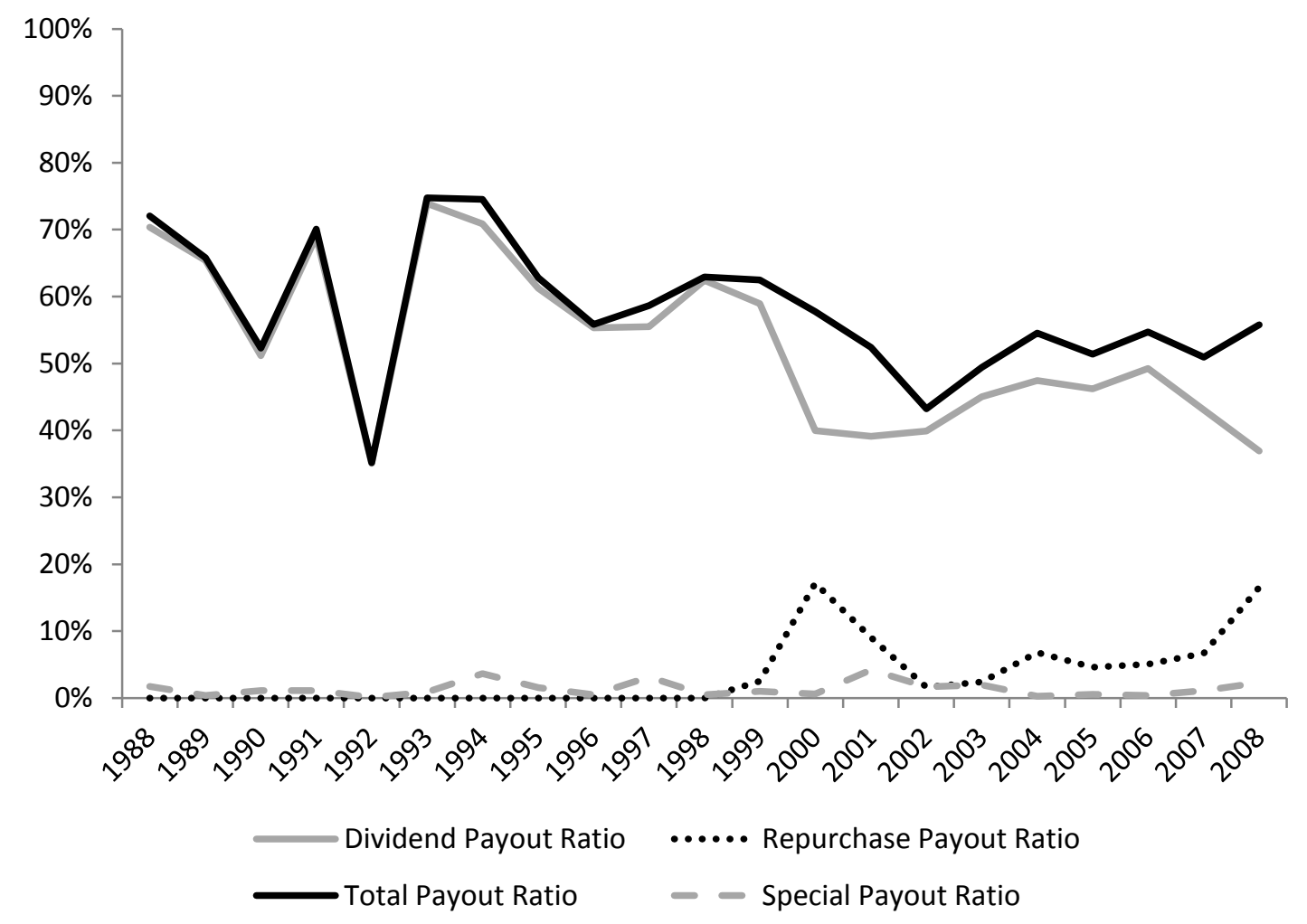




\section{Figure 2}

Percent of sample firms in different dividend groups

This figure depicts the distribution of the different dividend groups. A firm-year observation is defined as 'payer' if a firm pays a regular dividend in the relevant year. Otherwise, the observation is defined as 'nonpayer'. For each non-payer, we track the entire history of dividend payments. A firm-year observation for a company that has not paid a regular dividend since its IPO is defined as 'never paid', a firm that is currently not paying a regular dividend, but did so in at least one firm-year after going public, as 'former payer'.

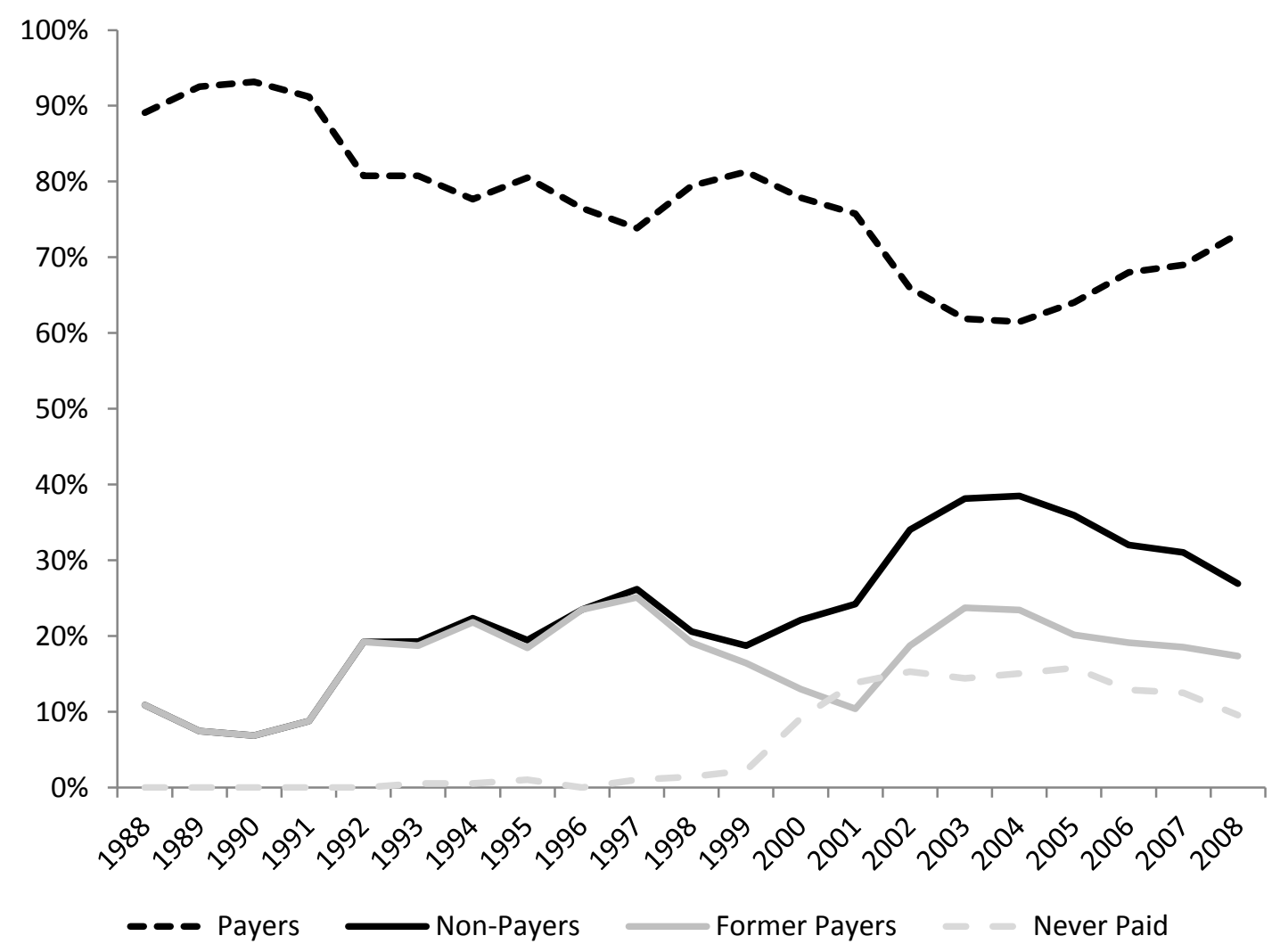


CFR Working Papers are available for download from www.cfr-cologne.de.

Hardcopies can be ordered from: Centre for Financial Research (CFR), Albertus Magnus Platz, 50923 Koeln, Germany.

\section{4}

No. Author(s) Title

14-10 O. Korn, P. Krischak, E. Illiquidity Transmission from Spot to Futures Markets Theissen

14-09 E. Theissen, L. S. Zehnder Estimation of Trading Costs: Trade Indicator Models Revisited

14-08

C. Fink, E. Theissen

Dividend Taxation and DAX Futures Prices

14-07 F. Brinkmann, O. Korn Risk-adjusted Option-implied Moments

14-06 J. Grammig, J. Sönksen Consumption-Based Asset Pricing with Rare Disaster Risk

14-05 J. Grammig, E. Schaub Give me strong moments and time - Combining GMM and SMM to estimate long-run risk asset pricing

14-04 C. Sorhage

14-03 D. Hess, P. Immenkötter

Outsourcing of Mutual Funds' Non-core Competencies and the Impact on Operational Outcomes: Evidence from Funds' Shareholder Services

How Much Is Too Much? Debt Capacity And Financial Flexibility

14-02 C. Andres, M. Doumet, E. The Lintner model revisited: Dividends versus total payouts Fernau, E. Theissen

14-01 N.F. Carline, S. C. Linn, P. Corporate Governance and the Nature of Takeover Resistance K. Yadav

\section{3}

No. Author(s) Title

13-11 R. Baule, O. Korn, S. Which Beta is Best? Saßning

On the Information Content of Option-implied Betas

13-10 V. Agarwal, L. Ma Managerial Multitasking in the Mutual Fund Industry

13-09 M. J. Kamstra, L.A. Kramer, M.D. Levi, R. Seasonal Asset Allocation: Evidence from Wermers Mutual Fund Flows 
13-08

F. Brinkmann, A. Kempf,

O. Korn

13-07 G. Cici, S. Gibson,

Y. Gunduz, J.J. Merrick, Jr.

13-06 S.Bethke, A. Kempf, M. Trapp

13-05 P. Schuster, M. Trapp, M. Uhrig-Homburg

13-04 V. Agarwal, K. Mullally, Y. Tang, B. Yang

13-03 V. Agarwal, V. Nanda, S.Ray

13-02 C. Andres, A. Betzer, M. Doumet, E. Theissen

13-01 J. Gaul, E. Theissen
Forward-Looking Measures of Higher-Order Dependencies with an Application to Portfolio Selection

Market Transparency and the Marking Precision of Bond Mutual Fund Managers

The Correlation Puzzle: The Interaction of Bond and Risk Correlation

A Heterogeneous Agents Equilibrium Model for the Term Structure of Bond Market Liquidity

Mandatory Portfolio Disclosure, Stock Liquidity, and Mutual Fund Performance

Institutional Investment and Intermediation in the Hedge Fund Industry

Open Market Share Repurchases in Germany: A Conditional Event Study Approach

A Partially Linear Approach to Modelling the Dynamics of Spot and Futures Price

\section{2}

\begin{tabular}{|c|c|c|}
\hline No. & Author(s) & Title \\
\hline $12-12$ & $\begin{array}{l}\text { Y. Gündüz, J. Nasev, } \\
\text { M. Trapp }\end{array}$ & The Price Impact of CDS Trading \\
\hline $12-11$ & $\begin{array}{l}\text { Y. Wu, R. Wermers, } \\
\text { J. Zechner }\end{array}$ & $\begin{array}{l}\text { Governance and Shareholder Value in Delegated Portfolio } \\
\text { Management: The Case of Closed-End Funds }\end{array}$ \\
\hline $12-10$ & M. Trapp, C. Wewel & Transatlantic Systemic Risk \\
\hline $12-09$ & $\begin{array}{l}\text { G. Cici, A. Kempf, } \\
\text { C. Sorhage }\end{array}$ & $\begin{array}{l}\text { Do Financial Advisors Provide Tangible Benefits for Investors? } \\
\text { Evidence from Tax-Motivated Mutual Fund Flows }\end{array}$ \\
\hline $12-08$ & S. Jank & $\begin{array}{l}\text { Changes in the composition of publicly traded firms: } \\
\text { Implications for the dividend-price ratio and return predictability }\end{array}$ \\
\hline $12-07$ & G. Cici, C. Rosenfeld & The Investment Abilities of Mutual Fund Buy-Side Analysts \\
\hline $12-06$ & $\begin{array}{l}\text { A. Kempf, A. Pütz, } \\
\text { F. Sonnenburg }\end{array}$ & $\begin{array}{l}\text { Fund Manager Duality: Impact on Performance and Investment } \\
\text { Behavior }\end{array}$ \\
\hline $12-05$ & R. Wermers & Runs on Money Market Mutual Funds \\
\hline $12-04$ & R. Wermers & $\begin{array}{l}\text { A matter of style: The causes and consequences of style drift } \\
\text { in institutional portfolios }\end{array}$ \\
\hline $12-02$ & $\begin{array}{l}\text { C. Andres, E. Fernau, } \\
\text { E. Theissen }\end{array}$ & $\begin{array}{l}\text { Should I Stay or Should I Go? } \\
\text { Former CEOs as Monitors }\end{array}$ \\
\hline $12-01$ & L. Andreu, A. Pütz & $\begin{array}{l}\text { Are Two Business Degrees Better Than One? } \\
\text { Evidence from Mutual Fund Managers' Education }\end{array}$ \\
\hline
\end{tabular}


2011

No. $\quad$ Author(s) Title

11-16 V. Agarwal, J.-P. Gómez, Management Compensation and Market Timing under Portfolio R. Priestley Constraints

11-15 T. Dimpfl, S. Jank

11-14 P. Gomber,

U. Schweickert,

E. Theissen

11-13 D. Hess, S. Orbe

11-12 D. Hess, P. Immenkötter

11-11 N. Heinrichs, D. Hess,

C. Homburg, M. Lorenz,

11-10 A. Kempf, O. Korn,

S. Saßning

11-09 V. Agarwal, S. Ray

11-08 G. Cici, L.-F. Palacios

11-07 V. Agarwal, G. D. Gay, L. Ling

11-06 N. Hautsch, D. Hess,

D. Veredas

11-05 G. Cici

11-04 S. Jank

11-03 G.Fellner, E.Theissen

11-02 S.Jank

11-01 V. Agarwal, C. Meneghetti The Role of Hedge Funds as Primary Lenders Volatility?

An Event Study Approach Implications from the Anchoring Bias Test Fund Industry They Are Doing? window-dressing behavior Noise, and Informational Volatility Trades Value: Evidence from the Laboratory
S. Sievers

Can Internet Search Queries Help to Predict Stock Market

Liquidity Dynamics in an Electronic Open Limit Order Book:

Irrationality or Efficiency of Macroeconomic Survey Forecasts?

Optimal Leverage, its Benefits, and the Business Cycle

Extended Dividend, Cash Flow and Residual Income Valuation Models - Accounting for Deviations from Ideal Conditions

Portfolio Optimization using Forward - Looking Information

Determinants and Implications of Fee Changes in the Hedge

On the Use of Options by Mutual Funds: Do They Know What

Performance inconsistency in mutual funds: An investigation of

The Impact of Macroeconomic News on Quote Adjustments,

The Prevalence of the Disposition Effect in Mutual Funds'

Mutual Fund Flows, Expected Returns and the Real Economy

Short Sale Constraints, Divergence of Opinion and Asset

Are There Disadvantaged Clienteles in Mutual Funds?

2010

No. Author(s)

Title

10-20 G. Cici, S. Gibson,

Missing the Marks? Dispersion in Corporate Bond Valuations J.J. Merrick Jr. Across Mutual Funds

10-19 J. Hengelbrock,

E. Theissen, C. Westheide

10-18 G. Cici, S. Gibson

Market Response to Investor Sentiment

The Performance of Corporate-Bond Mutual Funds:

Evidence Based on Security-Level Holdings

10-17 D. Hess, D. Kreutzmann,

O. Pucker
Projected Earnings Accuracy and the Profitability of Stock

Recommendations 
10-15

G. Cici, A. Kempf, A. Puetz

10-14

J. Grammig, S. Jank

10-13 S. Jank, M. Wedow

10-12 S. Artmann, P. Finter,

A. Kempf, S. Koch,

E. Theissen

10-11 M. Chesney, A. Kempf

10-10 S. Frey, P. Herbst

10-09 V. Agarwal, W. Jiang, Y. Tang, B. Yang

10-08 V. Agarwal, V. Fos, W. Jiang

10-07 V. Agarwal, G. Bakshi, J. Huij

10-06 J. Grammig, F. J. Peter

10-05 K. Drachter, A. Kempf

10-04 J. Fang, A. Kempf, M. Trapp

10-03 P. Finter, A. NiessenRuenzi, S. Ruenzi

10-02 D. Hunter, E. Kandel,

S. Kandel, R. Wermers

10-01 S. Artmann, P. Finter, A. Kempf
Sturm und Drang in Money Market Funds: When Money Market Funds Cease to Be Narrow

The Valuation of Hedge Funds' Equity Positions

Creative Destruction and Asset Prices

Purchase and Redemption Decisions of Mutual Fund Investors and the Role of Fund Families

The Cross-Section of German Stock Returns:

New Data and New Evidence

The Value of Tradeability

The Influence of Buy-side Analysts on Mutual Fund Trading

Uncovering Hedge Fund Skill from the Portfolio Holdings They Hide

Inferring Reporting Biases in Hedge Fund Databases from Hedge Fund Equity Holdings

Do Higher-Moment Equity Risks Explain Hedge Fund Returns?

Tell-Tale Tails: A data driven approach to estimate unique market information shares

Höhe, Struktur und Determinanten der ManagervergütungEine Analyse der Fondsbranche in Deutschland

Fund Manager Allocation

The Impact of Investor Sentiment on the German Stock Market

Mutual Fund Performance Evaluation with Active Peer Benchmarks

Determinants of Expected Stock Returns: Large Sample Evidence from the German Market

\section{9}

No.

09-17

$09-16$

M. Trapp

$09-15$

A. Betzer, J. Gider, D.Metzger, E. Theissen

$09-14$
A. Kempf, O. Korn,

M. Uhrig-Homburg

09-13 W. Bühler, M. Trapp

$09-12$
Title

Price Discovery in Spot and Futures Markets:

A Reconsideration

Trading the Bond-CDS Basis - The Role of Credit Risk and Liquidity

Strategic Trading and Trade Reporting by Corporate Insiders

The Term Structure of Illiquidity Premia

Time-Varying Credit Risk and Liquidity Premia in Bond and CDS Markets

Explaining the Bond-CDS Basis - The Role of Credit Risk and Liquidity 
09-11 S. J. Taylor, P. K. Yadav, Cross-sectional analysis of risk-neutral skewness Y. Zhang

09-10 A. Kempf, C. Merkle,

Low Risk and High Return - Affective Attitudes and Stock

A. Niessen-Ruenzi

Market Expectations

09-09

V. Fotak, V. Raman,

P. K. Yadav

Naked Short Selling: The Emperor`s New Clothes?

09-08 F. Bardong, S.M. Bartram, P.K. Yadav

Informed Trading, Information Asymmetry and Pricing of Information Risk: Empirical Evidence from the NYSE

09-07 S. J. Taylor, P. K. Yadav, The information content of implied volatilities and model-free Y. Zhang volatility expectations: Evidence from options written on individual stocks

09-06 S. Frey, P. Sandas The Impact of Iceberg Orders in Limit Order Books

09-05 H. Beltran-Lopez, P. Giot, Commonalities in the Order Book

J. Grammig

09-04 J. Fang, S. Ruenzi

Rapid Trading bei deutschen Aktienfonds:

Evidenz aus einer großen deutschen Fondsgesellschaft

09-03 A. Banegas, B. Gillen, The Cross-Section of Conditional Mutual Fund Performance in

A. Timmermann, European Stock Markets

09-02 J. Grammig, A. Schrimpf, Long-Horizon Consumption Risk and the Cross-Section

M. Schuppli

of Returns: New Tests and International Evidence

09-01 O. Korn, P. Koziol

The Term Structure of Currency Hedge Ratios

2008

\begin{tabular}{|c|c|c|}
\hline No. & Author(s) & Title \\
\hline 08-12 & $\begin{array}{l}\text { U. Bonenkamp, } \\
\text { C. Homburg, A. Kempf }\end{array}$ & Fundamental Information in Technical Trading Strategies \\
\hline $08-11$ & O. Korn & Risk Management with Default-risky Forwards \\
\hline $08-10$ & J. Grammig, F.J. Peter & $\begin{array}{l}\text { International Price Discovery in the Presence } \\
\text { of Market Microstructure Effects }\end{array}$ \\
\hline 08-09 & C. M. Kuhnen, A. Niessen & Public Opinion and Executive Compensation \\
\hline $08-08$ & A. Pütz, S. Ruenzi & $\begin{array}{l}\text { Overconfidence among Professional Investors: Evidence from } \\
\text { Mutual Fund Managers }\end{array}$ \\
\hline 08-07 & P. Osthoff & What matters to SRI investors? \\
\hline 08-06 & A. Betzer, E. Theissen & $\begin{array}{l}\text { Sooner Or Later: Delays in Trade Reporting by Corporate } \\
\text { Insiders }\end{array}$ \\
\hline 08-05 & P. Linge, E. Theissen & $\begin{array}{l}\text { Determinanten der Aktionärspräsenz auf } \\
\text { Hauptversammlungen deutscher Aktiengesellschaften }\end{array}$ \\
\hline $08-04$ & $\begin{array}{l}\text { N. Hautsch, D. Hess, } \\
\text { C. Müller }\end{array}$ & Price Adjustment to News with Uncertain Precision \\
\hline 08-03 & $\begin{array}{l}\text { D. Hess, H. Huang, } \\
\text { A. Niessen }\end{array}$ & $\begin{array}{l}\text { How Do Commodity Futures Respond to Macroeconomic } \\
\text { News? }\end{array}$ \\
\hline 08-02 & $\begin{array}{l}\text { R. Chakrabarti, } \\
\text { W. Megginson, P. Yadav }\end{array}$ & Corporate Governance in India \\
\hline $08-01$ & C. Andres, E. Theissen & $\begin{array}{l}\text { Setting a Fox to Keep the Geese - Does the Comply-or-Explain } \\
\text { Principle Work? }\end{array}$ \\
\hline
\end{tabular}




\begin{tabular}{|c|c|c|}
\hline No. & Author(s) & Title \\
\hline 07-16 & $\begin{array}{l}\text { M. Bär, A. Niessen, } \\
\text { S. Ruenzi }\end{array}$ & $\begin{array}{l}\text { The Impact of Work Group Diversity on Performance: } \\
\text { Large Sample Evidence from the Mutual Fund Industry }\end{array}$ \\
\hline 07-15 & A. Niessen, S. Ruenzi & $\begin{array}{l}\text { Political Connectedness and Firm Performance: } \\
\text { Evidence From Germany }\end{array}$ \\
\hline 07-14 & O. Korn & Hedging Price Risk when Payment Dates are Uncertain \\
\hline $07-13$ & A. Kempf, P. Osthoff & SRI Funds: Nomen est Omen \\
\hline 07-12 & $\begin{array}{l}\text { J. Grammig, E. Theissen, } \\
\text { O. Wuensche }\end{array}$ & Time and Price Impact of a Trade: A Structural Approach \\
\hline $07-11$ & V. Agarwal, J. R. Kale & $\begin{array}{l}\text { On the Relative Performance of Multi-Strategy and Funds of } \\
\text { Hedge Funds }\end{array}$ \\
\hline $07-10$ & $\begin{array}{l}\text { M. Kasch-Haroutounian, } \\
\text { E. Theissen }\end{array}$ & Competition Between Exchanges: Euronext versus Xetra \\
\hline 07-09 & $\begin{array}{l}\text { V. Agarwal, N. D. Daniel, } \\
\text { N. Y. Naik }\end{array}$ & Do hedge funds manage their reported returns? \\
\hline 07-08 & $\begin{array}{l}\text { N. C. Brown, K. D. Wei, } \\
\text { R. Wermers }\end{array}$ & $\begin{array}{l}\text { Analyst Recommendations, Mutual Fund Herding, and } \\
\text { Overreaction in Stock Prices }\end{array}$ \\
\hline 07-07 & A. Betzer, E. Theissen & $\begin{array}{l}\text { Insider Trading and Corporate Governance: } \\
\text { The Case of Germany }\end{array}$ \\
\hline 07-06 & V. Agarwal, L. Wang & Transaction Costs and Value Premium \\
\hline 07-05 & J. Grammig, A. Schrimpf & $\begin{array}{l}\text { Asset Pricing with a Reference Level of Consumption: } \\
\text { New Evidence from the Cross-Section of Stock Returns }\end{array}$ \\
\hline 07-04 & $\begin{array}{l}\text { V. Agarwal, N.M. Boyson, } \\
\text { N.Y. Naik }\end{array}$ & $\begin{array}{l}\text { Hedge Funds for retail investors? } \\
\text { An examination of hedged mutual funds }\end{array}$ \\
\hline 07-03 & D. Hess, A. Niessen & $\begin{array}{l}\text { The Early News Catches the Attention: } \\
\text { On the Relative Price Impact of Similar Economic Indicators }\end{array}$ \\
\hline 07-02 & $\begin{array}{l}\text { A. Kempf, S. Ruenzi, } \\
\text { T. Thiele }\end{array}$ & $\begin{array}{l}\text { Employment Risk, Compensation Incentives and Managerial } \\
\text { Risk Taking - Evidence from the Mutual Fund Industry - }\end{array}$ \\
\hline 07-01 & M. Hagemeister, A. Kempf & $\begin{array}{l}\text { CAPM und erwartete Renditen: Eine Untersuchung auf Basis } \\
\text { der Erwartung von Marktteilnehmern }\end{array}$ \\
\hline
\end{tabular}

2006

\begin{tabular}{|c|c|c|}
\hline No. & Author(s) & Title \\
\hline 06-13 & $\begin{array}{l}\text { S. Čeljo-Hörhager, } \\
\text { A. Niessen }\end{array}$ & $\begin{array}{l}\text { How do Self-fulfilling Prophecies affect Financial Ratings? - An } \\
\text { experimental study }\end{array}$ \\
\hline 06-12 & $\begin{array}{l}\text { R. Wermers, Y. Wu, } \\
\text { J. Zechner }\end{array}$ & $\begin{array}{l}\text { Portfolio Performance, Discount Dynamics, and the Turnover } \\
\text { of Closed-End Fund Managers }\end{array}$ \\
\hline 06-11 & $\begin{array}{l}\text { U. v. Lilienfeld-Toal, } \\
\text { S. Ruenzi }\end{array}$ & $\begin{array}{l}\text { Why Managers Hold Shares of Their Firm: An Empirical } \\
\text { Analysis }\end{array}$ \\
\hline $06-10$ & A. Kempf, P. Osthoff & $\begin{array}{l}\text { The Effect of Socially Responsible Investing on Portfolio } \\
\text { Performance }\end{array}$ \\
\hline 06-09 & $\begin{array}{l}\text { R. Wermers, T. Yao, } \\
\text { J. Zhao }\end{array}$ & $\begin{array}{l}\text { Extracting Stock Selection Information from Mutual Fund } \\
\text { holdings: An Efficient Aggregation Approach }\end{array}$ \\
\hline 06-08 & M. Hoffmann, B. Kempa & $\begin{array}{l}\text { The Poole Analysis in the New Open Economy } \\
\text { Macroeconomic Framework }\end{array}$ \\
\hline
\end{tabular}


06-07

J.P. Krahnen, F.A. Schmid, E. Theissen

06-05

S. Ber, S. Ruenzi

06-04

06-03

A. Kempf, D. Mayston

O. Korn, C. Koziol

06-02 O. Scaillet, L. Barras, R. Wermers

06-01 A. Niessen, S. Ruenzi
Decision Processes in German Mutual Fund Companies:

Evidence from a Telephone Survey

Investment Performance and Market Share: A Study of the German Mutual Fund Industry

On the Usability of Synthetic Measures of Mutual Fund NetFlows

Liquidity Commonality Beyond Best Prices

Bond Portfolio Optimization: A Risk-Return Approach

False Discoveries in Mutual Fund Performance: Measuring Luck in Estimated Alphas

Sex Matters: Gender Differences in a Professional Setting

2005

\begin{tabular}{|c|c|c|}
\hline No. & Author(s) & Title \\
\hline $05-16$ & E. Theissen & $\begin{array}{l}\text { An Analysis of Private Investors' Stock Market Return } \\
\text { Forecasts }\end{array}$ \\
\hline 05-15 & $\begin{array}{l}\text { T. Foucault, S. Moinas, } \\
\text { E. Theissen }\end{array}$ & Does Anonymity Matter in Electronic Limit Order Markets \\
\hline $05-14$ & $\begin{array}{l}\text { R. Kosowski, } \\
\text { A. Timmermann, } \\
\text { R. Wermers, H. White }\end{array}$ & $\begin{array}{l}\text { Can Mutual Fund „Stars“ Really Pick Stocks? } \\
\text { New Evidence from a Bootstrap Analysis }\end{array}$ \\
\hline $05-13$ & D. Avramov, R. Wermers & Investing in Mutual Funds when Returns are Predictable \\
\hline $05-12$ & K. Griese, A. Kempf & Liquiditätsdynamik am deutschen Aktienmarkt \\
\hline $05-11$ & $\begin{array}{l}\text { S. Ber, A. Kempf, } \\
\text { S. Ruenzi }\end{array}$ & Determinanten der Mittelzuflüsse bei deutschen Aktienfonds \\
\hline $05-10$ & $\begin{array}{l}\text { M. Bär, A. Kempf, } \\
\text { S. Ruenzi }\end{array}$ & $\begin{array}{l}\text { Is a Team Different From the Sum of Its Parts? } \\
\text { Evidence from Mutual Fund Managers }\end{array}$ \\
\hline 05-09 & M. Hoffmann & Saving, Investment and the Net Foreign Asset Position \\
\hline $05-08$ & S. Ruenzi & $\begin{array}{l}\text { Mutual Fund Growth in Standard and Specialist Market } \\
\text { Segments }\end{array}$ \\
\hline 05-07 & A. Kempf, S. Ruenzi & $\begin{array}{l}\text { Status Quo Bias and the Number of Alternatives - An Empirical } \\
\text { Illustration from the Mutual Fund Industry }\end{array}$ \\
\hline 05-06 & J. Grammig, E. Theissen & $\begin{array}{l}\text { Is Best Really Better? Internalization of Orders in an Open } \\
\text { Limit Order Book }\end{array}$ \\
\hline $05-05$ & $\begin{array}{l}\text { H. Beltran-Lopez, J. } \\
\text { Grammig, A.J. Menkveld }\end{array}$ & Limit order books and trade informativeness \\
\hline $05-04$ & M. Hoffmann & Compensating Wages under different Exchange rate Regimes \\
\hline $05-03$ & M. Hoffmann & $\begin{array}{l}\text { Fixed versus Flexible Exchange Rates: Evidence from } \\
\text { Developing Countries }\end{array}$ \\
\hline 05-02 & A. Kempf, C. Memmel & Estimating the Global Minimum Variance Portfolio \\
\hline 05-01 & S. Frey, J. Grammig & $\begin{array}{l}\text { Liquidity supply and adverse selection in a pure limit order } \\
\text { book market }\end{array}$ \\
\hline
\end{tabular}


No. Author(s) Title

04-10 N. Hautsch, D. Hess Bayesian Learning in Financial Markets - Testing for the Relevance of Information Precision in Price Discovery

04-09 A. Kempf, K. Kreuzberg Portfolio Disclosure, Portfolio Selection and Mutual Fund Performance Evaluation

04-08 N.F. Carline, S.C. Linn, Operating performance changes associated with corporate P.K. Yadav mergers and the role of corporate governance

04-07 J.J. Merrick, Jr., N.Y. Naik, Strategic Trading Behaviour and Price Distortion in a P.K. Yadav Manipulated Market: Anatomy of a Squeeze

04-06 N.Y. Naik, P.K. Yadav Trading Costs of Public Investors with Obligatory and Voluntary Market-Making: Evidence from Market Reforms

04-05 A. Kempf, S. Ruenzi

Family Matters: Rankings Within Fund Families and Fund Inflows

04-04 V. Agarwal, N.D. Daniel, N.Y. Naik

Role of Managerial Incentives and Discretion in Hedge Fund Performance

04-03 V. Agarwal, W.H. Fung, J.C. Loon, N.Y. Naik

Risk and Return in Convertible Arbitrage:

Evidence from the Convertible Bond Market

04-02 A. Kempf, S. Ruenzi

Tournaments in Mutual Fund Families

04-01 I. Chowdhury, M. Inflation Dynamics and the Cost Channel of Monetary Hoffmann, A. Schabert

Transmission 
